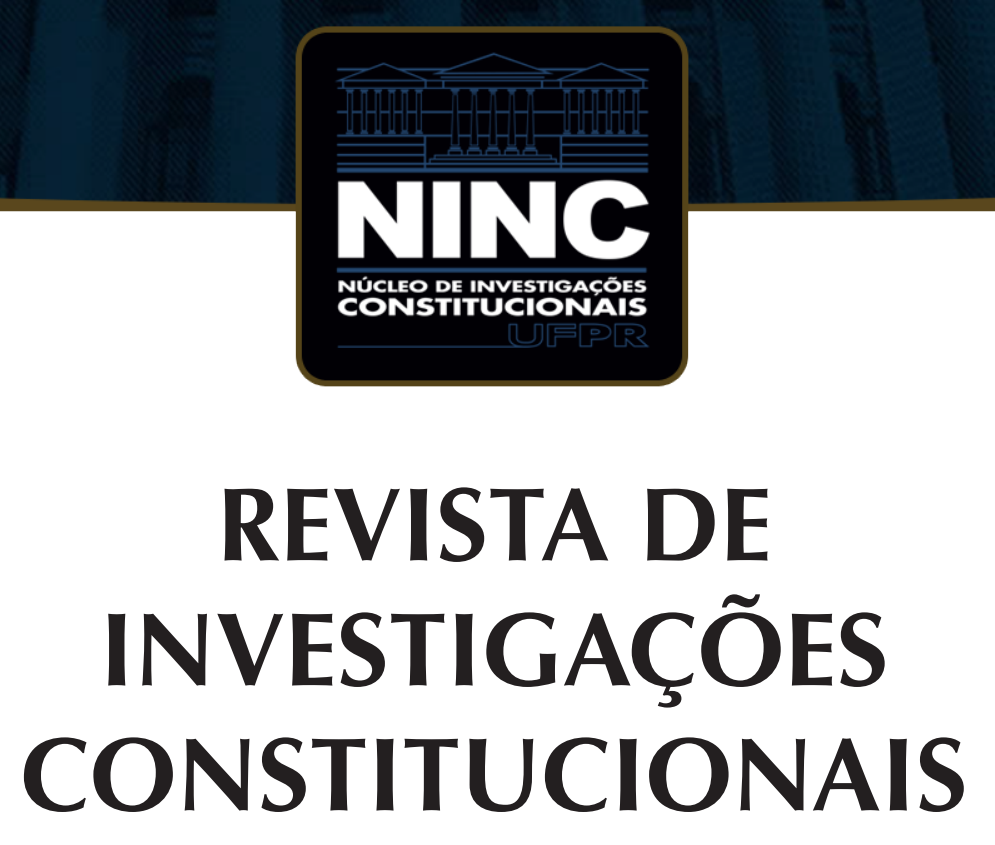

JOURNAL OF CONSTITUTIONAL RESEARCH

vol. 6 | n. 1 | janeiro/abril 2019 | ISSN 2359-5639 | Periodicidade quadrimestral Curitiba | Núcleo de Investigações Constitucionais da UFPR | www.ninc.com.br 


\section{Juiz constitucional e diálogo jurisdicional multinível: a experiência chilena*}

\section{Constitutional Court and Multilevel Jurisdictional Dialogue: the Chilean Experience}

\section{Resumo}

Este estudo começa examinando os casos Eichin e Antilef ante o Tribunal Constitucional chileno sobre a competência da justiça militar. Nestes casos, o Tribunal recorreu tanto à Convenção Americana sobre Direitos Humanos quanto à jurisprudência da Corte Interamericana de Direitos Humanos. A presente investigação aborda a questão da possibilidade de considerar os casos sobre justiça militar como exemplos de mudança de paradigma no direito público e diálogo entre tribunais. Propomos que os casos mencionados relativos à competência da justiça militar no Chile constituem um exemplo da transição para um novo paradigma constitucional caracterizado por uma intensificação do diálogo entre juízes em matéria de direitos humanos.

Palavras-chave: Corte Interamericana de Direitos $\mathrm{Hu}$ manos; diálogo entre juízes; jurisdição militar; jurisprudência interamericana; novo direito público.

\author{
GONZALO AGUILAR CAVALLO ${ }^{\mathrm{I}, * *}$ \\ IUniversidade de Talca (Chile) \\ gaguilarch@hotmail.com \\ Recebido/Received: 02.02.2018 / February 2 $2^{\text {nd }}, 2018$ \\ Aprovado/Approved: 30.04.2019 / April 30th', 2019
}

Abstract

This paper starts analyzing the Constitutional Court's Eichin and Antilef cases on the scope of the competence of the military justice in Chile. In Eichin and Antilef, the Constitutional Court applied both the Inter-American Convention on Human Rights and the Inter-American Court of Human Rights case-law. The research addresses the question of whether these cases reflect a paradigm shift in public Law and of dialogue between judges. We argue that Eichin and Antilef cases are examples of a process of transition toward a new constitutional paradigm, which is essentially marked by the intensification of the dialogue between judges in human rights.

Keywords: Inter-American Court of Human Rights; dialogue between judges; military justice; Inter-American case-law; new public law.

\footnotetext{
Como citar esse artigo/How to cite this article: AGUILAR CAVALLO, Gonzalo. Juiz constitucional e diálogo jurisdicional multinível: a experiência chilena. Revista de Investigações Constitucionais, Curitiba, vol. 6, n. 1, p. 61-89, jan./abr. 2019. DOI: 10.5380/ rinc.v6i1.57697.

* O autor agradece a tradução de Matheus Scandoleira e a colaboração de Maria Valentina de Moraes.

** Professor de Direito, Diretor do Mestrado em Direito Constitucional e Sub-Diretor do Centro de Estudios Constitucionales de Chile na Universidade de Talca (Santiago, Chile). Pós-Doutorado no Max Planck Institute for Comparative Public Law and International Law (Heidelberg, Alemanha). Doutor em Direito (Espanha), Mestrado em Relações Internacionais (Espanha), Mestrado em Direitos Humanos e Direito Humanitário (França). Advogado (Chile). E-mail: gaguilarch@hotmail.com.
} 


\section{SUMÁRIO}

1. Introdução; 2. Papel do juiz e diálogo jurisdicional; 2.1. Juiz nacional como juiz comum do direito europeu ou de direitos humanos; 2.2. Modalidades do diálogo entre juízes; 2.2.1. Diálogo sob o modo de interpretação conforme: diálogo conforme; 2.2.2. Diálogo sob o modo de interpretação construtiva: diálogo construtivo; 2.2.3. Diálogo sob o modo de interpretação antecipatória: diálogo antecipatório; 2.2.4. Diálogo sob o modo de interpretação neutralizante: diálogo neutralizante; 2.2.5. Diálogo sob o modo de interpretação contraditório: diálogo oposição; 3. A jurisprudência constitucional sobre jurisdição militar; 3.1. Os direitos reconhecidos em instrumentos internacionais de direitos humanos;: 3.1.1. Norma fundamental do bloco constitucional de direitos fundamentais; 3.1.2. Elemento interpretativo determinante ou papel significativo dos padrões internacionais; 3.2. Jurisprudência da Corte Interamericana de Direitos Humanos; 4. Conclusão; 5. Referências.

\section{INTRODUÇÃO}

No ano de 2014, o Tribunal Constitucional chileno pronunciou duas sentenças nas quais declara a inaplicabilidade por inconstitucionalidade da justiça militar em casos que envolvem vítimas civis ou cujas circunstâncias demonstram ser um ilícito penal comum. Em ambos os casos, o Tribunal fundamentou sua argumentação em abundantes referências tanto ao direito internacional convencional dos direitos humanos como à jurisprudência da Corte Interamericana de Direitos Humanos (Corte IDH). A partir destes exemplos, surgem as seguintes perguntas: Poderiam esses casos ser considerados uma demonstração do papel protagonista do juiz sob o prisma de um novo paradigma jurídico? Poderiam estes casos serem demonstrações do aumento potencial do papel do juiz constitucional no contexto do surgimento de um novo direito público? Existe nestes casos um diálogo entre juízes? Nossa posição consiste em argumentar que os julgados recentes do Tribunal Constitucional chileno, a propósito da competência da justiça militar, constituem uma amostra do que poderia denominar-se uma mudança de paradigma jurídico, especialmente no âmbito constitucional. Essa mudança de paradigma teria como pano de fundo a lenta emergência de um novo direito público, e como característica o papel protagonista do juiz e o diálogo multinível interjudicial.

Este trabalho tem por objeto analisar, no contexto chileno, se o papel protagonista do juiz, sobretudo no direito público, vem estimulando um diálogo entre tribunais de distintas jurisdições estatais, inclusive com jurisdições internacionais. Além disso, buscamos ilustrar a noção de diálogo e o papel do juiz em um emergente novo direito público através de casos da jurisprudência do Tribunal Constitucional chileno. Devemos deixar claro desde o princípio que nosso enfoque sobre o diálogo e o papel crescente do juiz como demonstração do surgimento de um novo direito público, se centra nos direitos humanos.

Por essa razão, este estudo se encontra dividido numa primeira parte na qual, a partir de exemplos de casos jurisprudenciais, analisaremos o papel protagonista do 
juiz e o diálogo entre juízes. Numa segunda parte, abordaremos o exame dos casos jurisprudenciais relativos à competência da justiça militar, os quais podem revelar o papel de crescente importância do juiz, do diálogo interjurisdicional e do controle de convencionalidade.

\section{PAPEL DO JUIZ E DIÁLOGO JURISDICIONAL}

No mundo contemporâneo e, em parte devido ao processo de globalização, se desenvolveram distintos conceitos de diálogo'. Neste estudo, nos interessa, especialmente, o diálogo entre juízes e, particularmente, a esfera dos direitos humanos. Em que consiste esse diálogo? Poderia expressar-se em uma prática entre dois ou mais juízes que manifestam suas ideias tentando chegar a um acordo ${ }^{2}$. Nesse sentido, o diálogo entre juízes se entenderia como uma discussão, um acordo, uma busca por consenso, o que é especialmente relevante e potente no terreno dos direitos humanos. Sob esse prisma, o diálogo evita confusão quanto às coisas que atrapalham ou desunem e, evade, com certeza, toda comunicação que implique propor ou reconhecer a questão da autoridade de uns sobre outros ${ }^{3}$.

O diálogo entre juízes aparece como um elemento consubstancial ao que Bogdandy chama o novo direito público 4 . O diálogo entre juízes manifesta o novo paradigma do modelo constitucional multinível ${ }^{5}$. Efetivamente, esses intercâmbios, comunicações, debates ou confrontações entre juízes sobre o sentido e alcance de uma disposição de direitos humanos podem ocorrer entre um juiz nacional e um juiz internacional ou supranacional ${ }^{6}$.

Sob esse novo paradigma, o juiz se vê na obrigação de justificar integralmente sua decisão, proporcionando argumentos suficientes e convincentes. Hoje em dia,

\footnotetext{
${ }^{1}$ BOGDANDY, Armin Von. Ius constitutionale commune latinoamericanum. Una aclaración conceptual desde una perspectiva europea. In: PÉREZ, L. R. G.; VALADÉS, D. (Coords.). El constitucionalismo contemporáneo. Homenaje a Jorge Carpizo. México: Instituto de Investigaciones jurídicas, UNAM, 2013. p. 39-66. p. 55.

${ }^{2} \mathrm{O}$ diálogo entre juízes significaria uma prática entre dois ou mais juízes ou órgãos jurisdicionais que alternativamente manifestam suas ideias em busca de conciliação. CAVALLO, Gonzalo Aguilar. Diálogo judicial multinivel. In: ALCALÁ, Humberto Nogueira (Coord.). Diálogo judicial multinivel y principios interpretativos favor persona y de proporcionalidad. Santiago: Librotecnia, 2013. p. 55-102.

${ }^{3}$ SUXE, Hervé. La dimension objective du dialogue des juges. Cahiers de I'IDEDH, Montpellier, n. 11, p. 158191. 2007 e GRABARCZYK, Kataryna. Dialogue des juges: éléments d'analyse. Cahiers de l'IDEDH, Montpellier, n. 11, p. 10-41, 2007. p. 21.

${ }^{4}$ BOGDANDY, Armin Von. lus constitutionale commune latinoamericanum. Una aclaración conceptual desde una perspectiva europea. In: PÉREZ, L. R. G.; VALADÉS, D. (Coords.). El constitucionalismo contemporáneo. Homenaje a Jorge Carpizo. México: Instituto de Investigaciones jurídicas, UNAM, 2013. p. 55.

${ }^{5}$ CAVALLO, Gonzalo Aguilar. Diálogo judicial multinivel. In: ALCALÁ, Humberto Nogueira (Coord.). Diálogo judicial multinivel y principios interpretativos favor persona y de proporcionalidad. Santiago: Librotecnia, 2013. p. 55-102.

${ }^{6}$ SUXE, Hervé. La dimension objective du dialogue des juges. Cahiers de I'IDEDH, Montpellier, n. 11, p. 158191. 2007. p. 158.
} 
o argumento de autoridade na decisão judicial se dá pela justificação proporcionada pelo juiz . O diálogo entre juízes é uma notável manifestação dos processos aos quais levou a globalização e o surgimento dos direitos humanos como um potencial direito mundial, infestado de uma constelação de direitos nacionais onde nenhuma ordem interna pode reclamar hierarquia sobre outra com base em uma ordem de precedência. Por isso, nesse contexto, a falta de hierarquia, o diálogo e a persuasão que o acompanha se transformam em uma ferramenta útil que se exercita através do direito comparado.

Esta seção aborda, em primeiro lugar, o juiz nacional como juiz de direitos humanos e, posteriormente, examina as diversas modalidades do diálogo que se concretizam por meio de diferentes tipos de interpretação dos direitos.

\subsection{Juiz nacional como juiz comum de direitos humanos}

O controle de convencionalidade converte o juiz nacional no juiz de direito comum. No âmbito da União Europeia será o juiz de direito comum do direito europeu . Na esfera da Convenção Europeia de Direitos Humanos será o juiz de direito comum da convencionalidade de direitos humanos.

Alguns afirmam, inclusive, que o juiz nacional, compreendendo o juiz constitucional, será o intérprete de direito comum da Convenção Europeia de Direitos Humanos ${ }^{9}$. Segundo Maus, este último seria o entendimento que se daria ao controle de convencionalidade pelos juízes nacionais no contexto do sistema europeu de direitos humanos. Efetivamente, “o sistema da Convenção Europeia pode ser aplicado também pelas jurisdições nacionais a título de controle de convencionalidade, quando estas devem descartar disposições do direito nacional por não respeitar as normas da Convenção Europeia tais como são interpretadas pela Corte"10.

Neste papel, o juiz nacional, aplicador e intérprete do direito comum de normas internacionais e supranacionais, adquirirá os poderes para descartar ou não aplicar

\footnotetext{
${ }^{7}$ BOGDANDY, Armin Von. Ius constitutionale commune latinoamericanum. Una aclaración conceptual desde una perspectiva europea. In: PÉREZ, L. R. G.; VALADÉS, D. (Coords.). El constitucionalismo contemporáneo. Homenaje a Jorge Carpizo. México: Instituto de Investigaciones jurídicas, UNAM, 2013. p. 55.

${ }^{8}$ LE POURHIET, Anne-Marie. L'allégeance des juges nationaux au juge européen, Constitutions. Revue de droit constitutionnel appliqué, França, n. 3, p. 363-365. 2010.

${ }^{9}$ ANDRIANTSIMBAZOVINA, Joël. La prise en compte de la Convention européenne des droits de l'homme par le Conseil constitutionnel, continuité ou évolution?, Cahiers du Conseil Constitutionnel, [s.l.], vol. 18, p. 148153, 2005 e LAVADE, Anne. Constitution et Europe ou le juge constitutionnel au cœur des rapports de systèmes, Cahiers du Conseil Constitutionnel, França, n. 18, p. 133-137. 2005.

${ }^{10}$ Ainda, segundo Maus "nenhuma jurisdição nacional considerou que, em sua ordem interna, disposições de valor constitucional deveriam ser descartadas como resultado do controle de convencionalidade. Apesar disso, tal hipótese não é inconcebível, em particular quando permanecem nas constituições nacionais normas que tenham sido adotadas num período democrático". MAUS, Didier. La Charte des Droits Fondamentaux de I'Union Européenne et la Protection des Droits de l'Homme en Europe. 2004. Disponível em: <http://www. us-rs.si/media/zbornik.pdf>. Acesso em: 31 fev. 2018. p. 14-26. p. 25.
} 
normas nacionais, inclusive disposições de valor constitucional, sobretudo quando estas entram em colisão ou produzem problemas de interpretação com normas internacionais e supranacionais, as quais, considerando sua interpretação autorizada, outorgam um padrão de proteção ao indivíduo mais elevado. ${ }^{11}$ Cabe observar aqui, sobretudo como lição para o Chile, que já faz mais de quinze anos que a jurisprudência do Tribunal Federal Suíço confirmou a primazia do direito internacional, sobretudo quando se trata de direitos humanos. ${ }^{12}$

Assim, o controle de convencionalidade e o diálogo entre juízes não significa submissão nem subordinação de nenhuma espécie. ${ }^{13}$ De fato, um tribunal nacional pode perfeitamente distanciar-se da postura de outro tribunal de direitos humanos, através da denominada interpretação construtiva, indo mais além do que a própria interpretação do órgão jurisdicional internacional, quando o princípio pro homine o exige, princípio que constitui o ponto principal do sistema de direitos humanos ${ }^{14}$. Nesta linha, a Corte Europeia de Direitos Humanos (Corte EDH), no famoso caso Sunday Times, afirmou que mesmo quando a Convenção Europeia de Direitos Humanos estabelece certos padrões internacionais que devem ser observados pelos Estados contratantes, "isso não quer dizer que uma uniformidade absoluta é requerida, e, efetivamente, por mais que os Estados contratantes sejam livres para eleger as medidas que eles consideram apropriadas, a Corte não pode ser indiferente ante os traços substanciais ou processuais de suas respectivas normas internas"15.

\footnotetext{
${ }^{11}$ Referindo-se ao controle de convencionalidade, Randall confirma a faculdade dos juízes suíços de indeferir a aplicação de uma lei federal contrária à Convenção [Europeia de Direitos Humanos], apoiando-se, sobretudo, na primazia do direito internacional e na importância particular dos tratados em matéria de Direitos Humanos. RANDALL, Maya Hertig. Le dialogue entre le juge suisse et le juge européen. In: BELLANGER, Francois; WERRA, Jacques (Coords.). Genève au confluent du droit interne et du droit international: Mélanges offerts par la Faculté de droit de I'Université de Genève à la Société suisse des juristes à l'occasion du congrès 2012. Zürich: Schulthess, 2012. p. 29.

12 "Diese völkerrechtlichenPrinzipiensind in der schweizerischenRechtsordnungunmittelbaranwendbar (BGE 117 lb 337 E. 2a S. 340) undbindennichtnurdenGesetzgeber, sondernsämtlicheStaatsorgane (vgl. die gemeinsameStellungnahmedesBundesamtesfürJustizund der DirektionfürVölkerrechtvom 26. April 1989, VPB 53/1989 Nr. 54 Ziff. 15 S. 420 ff.). Darausergibtsich, dassimKonfliktfall das VölkerrechtdemLandesrechtprinzipiellvorgeht (BGE 122 II 485 E. 3a S. 487; BGE 122 II 234 E. 4e S. 239; BGE 109 lb 165 E. 7b S. 173; BGE 100 la 407 E. 1b S. 410; BGE 125 III 209 E. 6e in fine). Dies hatzurFolge, dasseinevölkerrechtswidrige Norm desLandesrechtsimEinzelfallnichtangewendetwerdenkann. Diese Konfliktregelungdrängtsichumsomehrauf, wennsich der Vorrangauseinervölkerrechtlichen Norm ableitet, die demSchutz der Menschenrechtedient." ATF 125/1999 II 417. Urteil der I. öffentlichrechtlichenAbteilungvom 26. Juli 1999 i.S. A.gegenSchweizerischeBundesanwaltschaft, EidgenössischesJustizundPolizeidepartementundSchweizerischenBundesrat (Verwaltungsgerichtsbeschwerde). Consid. 4 d).

13 "As autoridades nacionais permanecem livres para eleger as medidas que considerem apropriadas para a implementação de suas obrigações convencionais". SUDRE, Frédéric. Droit européen et international des droits de l'homme. Paris: PUF, 2003. p. 200.
}

${ }^{14}$ SUDRE, Frédéric. Droit européen et international des droits de l’homme. Paris: PUF, 2003.

15 “Isso não significa que a uniformidade absoluta é requerida e, de fato, desde que os Estados Contratantes permaneçam livres para escolher as medidas que considerem apropriadas, a Corte não pode estar alheia às características materiais ou procedimentais de suas respectivas leis domésticas". CONSELHO DA EUROPA. 
Em suma, o critério regente que guia e ilumina a atuação do juiz nacional foi esclarecido pela doutrina e pela jurisprudência. De fato, o que se requer ao momento de proporcionar uma tutela judicial efetiva a um direito é determinar qual das diversas fontes disponíveis oferece um nível de proteção mais adequado, levando em consideração a jurisprudência pertinente. ${ }^{16}$

Essa é a experiência que nos demonstrou o Tribunal Constitucional alemão nos casos Solange 1 (1974) e Solange 2 (1998), no sentido da supremacia do direito comunitário ou europeu, enquanto mantenha, ao menos, o mesmo nível de proteção que proporciona o sistema constitucional de direitos fundamentais ${ }^{17}$.

$\mathrm{O}$ uso do direito internacional dos direitos humanos por parte do juiz nacional através do mecanismo de controle de convencionalidade convertendo-o no juiz comum dos direitos humanos permite visualizar uma realidade prática, a qual é a existência de um diálogo. Os distintos intercâmbios entre o juiz nacional e o juiz internacional se produzem em vários sentidos e o resultado disso pode ser incerto, como se verá em seguida, dependendo do tipo de diálogo que se entabule.

Como adiante se verá na segunda parte, o juiz constitucional chileno, vem realizando essa mesma indagação em casos da justiça militar, tentando determinar qual é o padrão de proteção mais alto, o nacional ou o internacional. Nesse processo indagatório, o juiz nacional chileno recorre a algumas das distintas fórmulas de diálogo entre juízes.

\subsection{Modalidades do diálogo entre juízes}

As distintas modalidades de diálogo se apresentam ao amparo da interpretação em direitos humanos. Por isso que os distintos tipos de diálogo se traduzem em distintas variedades de interpretação. Nossa postura inicial é a de que o juiz constitucional chileno nos casos Eichin e Antilef realizou um tipo específico de diálogo e, portanto, recorreu a uma variedade determinada de interpretação, das que serão analisadas a seguir. Em outras palavras, Eichin e Antilef seriam dois exemplos da realidade deste diálogo entre juízes na ordem constitucional chilena. Tentaremos, neste trabalho, dar

\footnotetext{
Tribunal Europeu dos Direitos Humanos. Pedido n 6538/74 (caso do Sunday Times contra o Reino Unido). Par. 61. Julgamento em 26/04/1979.

${ }^{16}$ Tria indica que se o juiz nacional necessita recorrer a fontes supranacionais e/ou internacionais para prestar uma melhor tutela, "deve determinar qual das mencionadas fontes oferece um nível de proteção mais adequado, levando também em consideração a jurisprudência pertinente da Corte de Luxemburgo e Estrasburgo". TRIA, Lucia. La tutela dei diritti fondamentali. In: Le tecniche di interrelazione normativa indicate dalla Corte costituzionale. L'abilità di usare il patrimonio di sapienza giuridica ereditato dal passato per preparare il futuro. 2014. p. 34. Disponível em: <http://www.cortecostituzionale.it/documenti/convegni_seminari/STU_274. pdf>. Acesso em 31 fev. 2018.

${ }^{17}$ ALEMANHA. Tribunal Constitucional Alemão, BVerfGE 37, 27, Caso Handelsgesellschaft, ("Solange I"). Julgado em 29/05/1974. Disponível em: <https://www.bundesverfassungsgericht.de>.
} 
um contexto teórico à experiência derivada da prática constitucional chilena nos casos mencionados.

Para efetuar a análise das distintas modalidades que pode adquirir o diálogo entre juízes, talvez convenha levar em consideração, primeiro que "o diálogo entre jurisdições não se pode conceber sem certa autonomia do juiz nacional"18. Por outro lado, cabe ressaltar que a controvérsia é necessária para que exista um diálogo produtivo e enriquecedor, porque a concordância pura e simples, na realidade, se parece mais a um monólogo que a um diálogo ${ }^{19}$.

Tal como mencionamos anteriormente, o diálogo entre juízes pode adquirir a forma de uma controvérsia, uma discussão, uma confrontação, um debate ou um intercâmbio de argumentos acerca do sentido e alcance de uma norma de direitos humanos, entre um juiz nacional e um juiz internacional ${ }^{20}$.

O intercâmbio ou debate de raciocínios ou argumentações exige naturalmente do juiz interno um exercício de interpretação. Este exercício, como advertimos, se veicula, tanto na Europa como na América, preferencialmente através do controle de convencionalidade. Assim, os modos de interpretação acumulados pelo juiz interno no exercício do controle de convencionalidade aparecem como fundamentais para o desenvolvimento do diálogo entre juízes. O diálogo entre juízes e as distintas formas de interpretação que este implica vem sendo abordados principalmente pela doutrina Europeia com base na experiência cotidiana, sobretudo, derivada da interação com o sistema europeu de direitos humanos. O diálogo de juízes abrange vários modos de interpretação em direitos humanos, tais como a interpretação neutralizante e a interpretação conforme ${ }^{21}$. Igualmente, o diálogo se pode materializar através da interpretação, contradição ou antecipação ${ }^{22}$. Além disso, Regis de Gouttes, referindo-se ao papel que desempenha a norma convencional para o juiz nacional, alude a uma função reveladora e alternativa da lei nacional ${ }^{23}$.

Todavia, em nossa visão, e pondo a salvo o caso do princípio de interpretação conforme, estas manifestações de diálogo não correspondem a princípios de interpretação em si mesmos considerados, e sim melhor ao resultado produto da atividade

\footnotetext{
${ }^{18}$ GRABARCZYK, Kataryna. Dialogue des juges: éléments d'analyse. Cahiers de I'IDEDH, Montpellier, n. 11, p. 10-41, 2007. p. 25.

${ }^{19}$ GRABARCZYK, Kataryna. Dialogue des juges: éléments d'analyse. Cahiers de I'IDEDH, Montpellier, n. 11, p. 10-41, 2007.

${ }^{20}$ GRABARCZYK, Kataryna. Dialogue des juges: éléments d'analyse. Cahiers de I'IDEDH, Montpellier, n. 11, p. 10-41, 2007.

${ }^{21}$ SUDRE, Frédéric. Avant-propos. Cahiers de I'IDEDH, Montpellier, n. 11, p. 7-9. 2007 e GRABARCZYK, Kataryna. Dialogue des juges: éléments d'analyse. Cahiers de I'IDEDH, Montpellier, n. 11, p. 10-41, 2007.

${ }^{22}$ GRABARCZYK, Kataryna. Dialogue des juges: éléments d'analyse. Cahiers de I'IDEDH, Montpellier, n. 11, p. 10-41, 2007.

${ }^{23}$ GOUTTES, Régis de. La Convention européenne des droits de l'homme et le juge français. Revue internationale de droit comparé, França, vol. 51, n. 1, p. 7-20, jan./mar. 1999.
} 
interpretativa, tais como contradição, neutralização ou antecipação. A partir das propostas precedentes de Sudre, Grabarczyk e De Goutte, em seguida examinaremos brevemente o que sugerimos denominar como o diálogo conforme, construtivo, antecipatório, neutralizante, oposição ${ }^{24}$.

\subsubsection{Diálogo sob o modo de interpretação conforme: diálogo conforme}

No diálogo através da interpretação conforme a interpretação do direito nacional coincide com as interpretações dadas pelo juiz internacional de direitos humanos ${ }^{25}$. O diálogo de conformidade ou conforme se refere à técnica a qual recorre o juiz nacional para harmonizar o direito nacional com o instrumento internacional convencional e corresponde especificamente à interpretação conforme a Convenção ${ }^{26}$. Como assinala Randall "a interpretação conforme a Convenção deriva da interpretação conforme ao direito internacional"27. Um exemplo claro de interpretação conforme a Convenção, emanado do direito suíço, se refere a um caso em que os juízes federais aplicaram o artigo 98, alínea 4 (matrimônio de estrangeiros em situação irregular) do Código Civil suíço em forma conforme ao direito ao matrimônio consagrado no art. 12 da Convenção Europeia de Direitos Humanos. Essa regra de interpretação conforme estimula um diálogo que aponta a evitar a maior parte dos conflitos entre ambas as ordens, doméstica e internacional.

A interpretação conforme a Convenção, e mais genericamente, ao direito internacional, aponta a alcançar a convergência de interpretação do juiz nacional com aquela do juiz internacional, ajustando-a a seus limites e conteúdos. Os juízes constitucionais chilenos assim procederam em diversas ocasiões ao entabular esse tipo de diálogos, realizando a interpretação conforme. Por exemplo, em matéria de direitos da criança (a respeito dos quais a Constituição chilena guarda absoluto silêncio), o Tribunal Constitucional do Chile declarou a inaplicabilidade por inconstitucionalidade de normas da Lei 19.968, que criou os Tribunais de Família, considerando para declará-la

\footnotetext{
${ }^{24}$ ALCALÁ, Humberto Nogueira. Derechos fundamentales, bloque constitucional de derechos, diálogo interjurisdiccional y control de convencionalidad. México: Ubijus, 2014 e DULITZKY, Ariel. E.. An Inter-American Constitutional Court? The Invention of the Conventionality Control by the Inter-American Court of Human Rights. Texas International Law Journal, Texas, vol. 50, n. 1, p. 45-93, dec./feb. 2015.

${ }^{25}$ SAGÜES, Néstor Pedro. El 'control de convencionalidad' en el sistema interamericano, y sus anticipos en el ámbito de los derechos económicos-sociales. Concordancias y diferencias con el sistema europeo. In: BOGDANDY, Armin von; FIX-FIERRO, Héctor; ANTONIAZZI, Mariela Morales; MAC-GREGOR, Eduardo Ferrer (Coords.). Construcción y papel de los derechos sociales fundamentales: Hacia un ius constitutionale commune en América Latina. México: UNAM-Instituto de Investigaciones Jurídicas de México, 2011. p. 381-417.

${ }^{26} \mathrm{MAC}-\mathrm{GREGOR}$, Eduardo Ferrer. Interpretación conforme y control difuso de convencionalidad. El nuevo paradigma para el juez mexicano. Estudios Constitucionales, Talca, vol. 9, n 2, p. 531-622. 2011.

${ }^{27}$ RANDALL, Maya Hertig. Le dialogue entre le juge suisse et le juge européen. In: BELLANGER, Francois; WERRA, Jacques (Coords.). Genève au confluent du droit interne et du droit international: Mélanges offerts par la Faculté de droit de I'Université de Genève à la Société suisse des juristes à l'occasion du congrès 2012. Zürich: Schulthess, 2012. p. 19-59.
} 
não somente a conformidade a normas internacionais mas também a interpretação proveniente da Corte IDH. ${ }^{28}$

Assim, nestes casos, produto deste diálogo, o juiz nacional descarta a norma nacional, distanciando-se da jurisprudência constitucional, justamente porque praticando o controle difuso de convencionalidade, o juiz interno controverte abertamente o enfoque proposto pelo órgão jurisdicional constitucional. A este tipo de juiz, Motolese os chama os "juízes verdadeiramente", uma vez que conhecem a jurisprudência constitucional e são conscientes de que a estão controvertendo, aplicando um diálogo conforme à norma convencional ${ }^{29}$. Por sua parte, Regis de Gouttes se refere a este tipo de situação como uma verdadeira neutralização da lei nacional, já que o juiz nacional, aplicando a norma convencional, neutraliza o texto da lei interna não compatível com as exigências da Convenção ${ }^{30}$. No caso da Corte Suprema chilena é possível encontrar exemplos relevantes deste tipo de interpretação. Por exemplo, no denominado caso dos Conselhos de Guerra de 2016, a Corte, executando uma decisão da Corte Interamericana de Direitos Humanos, endireita uma injustiça, anula Conselhos de Guerra realizados durante a época da ditadura, e aplica não somente as normas internacionais de direitos humanos como também a interpretação que delas realizou a Corte IDH. ${ }^{31}$

\footnotetext{
${ }^{28}$ "Que, além disso, a Convenção sobre os Direitos da Criança indica em seu artigo primeiro: 'criança (é) todo ser humano menor com menos de dezoito anos de idade, a não ser que, em conformidade com a lei aplicável à criança, a maioridade seja alcançada antes' (CORTE INTERAMERICANA DE DERECHOS HUMANOS. Caso "Niños de la Calle" - Villagrán Morales y otros vs. Guatemala. Julgado em 19/09/1999, parágrafo 188). Nas Regras de Pequim, nas Regras de Tókio e nas Diretrizes de Riad se utilizam os termos "criança" e "menor" para designar aos sujeitos destinatários de suas disposições. De acordo com as Regras de Pequim, "menor é toda criança ou jovem que, de acordo com o sistema jurídico respectivo, pode ser castigado por cometer um delito de forma diferente de um adulto". Nas Regras de Tókio não se estabelece ressalva alguma ao limite de dezoito anos.

Em definitiva, levando em conta a normativa internacional e o critério sustentado pela Corte Interamericana de Direitos Humanos, se entende por "criança" a toda pessoa que não haja cumprido dezoito anos (CORTE INTERAMERICANA DE DERECHOS HUMANOS. Opinião Consultiva OC-17/02. Condição Jurídica e Direitos Humanos da Criança. Publicada em 28/08/2002).

Desta maneira, a palavra "imputado" contraria a natureza e essência da Lei de Responsabilidade Penal Juvenil, a qual veio, em nosso país, dar cumprimento ao ordenado na Convenção dos Direitos da Criança, cujo fim era promover o estabelecimento de procedimentos, autoridades e instituições específicas para o julgamento de crianças aos quais se impute infração de lei penal, pelo que corresponde que os menores que estejam isentos sejam postos à disposição do tribunal competente em assuntos de família..." (Corte Suprema, casos 5440-2007, 5441-2007 e 5972-2009), (STC, casso n 2743 c. 13)". CHILE. Tribunal Constitucional. Requerimento de Inaplicabilidade por Inconstitucionalidade I-21-2016, RUC 16-2-0173337-9. Relator: Ministro Pilar Arellano Gómez, julgado em 04/07/2016. Disponível em: <http://www.tribunalconstitucional.cl/expediente?rol=3119>. Acesso em 30 fev. 2015.
}

${ }^{29}$ MOTOLESE, Luisa. La Corte Europea dei Diritti dell'Uomo: Tecniche di decisione e criteri di interpretazione conforme alla Convenzione Europea. 2013. Disponível em: <http://www.contabilita-pubblica.it/2013/Dottrina/Motolese.pdf>. Acesso em 5 jan. 2015.

${ }^{30}$ GOUTTES, Régis de. La Convention européenne des droits de l'homme et le juge français. Revue internationale de droit comparé, França, vol. 51, n. 1, p. 7-20, jan./mar. 1999.

${ }^{31}$ CHILE. Corte Suprema de Chile. Caso Conselhos de Guerra n 27.543-16. 2016. Disponível em: <http:// www.pjud.cl/corte-suprema>. Acesso em: 29 jan. 2018. 
Por outro lado, tal como se indicará na segunda parte deste trabalho, quando o Tribunal Constitucional chileno, em Eichin e Antilef - consequentemente em Jorqueraexpressa que os direitos contidos nos instrumentos internacionais de direitos humanos constituem uma fonte material para o juiz interno pela via do bloco constitucional de direitos fundamentais e seu conteúdo serve de elemento interpretativo determinante na análise constitucional jurisprudencial, e que os padrões internacionais cumprem um papel significativo, em nosso modo de ver, tal tribunal se posiciona no diálogo conforme. E, sobretudo, o juiz constitucional chileno empreende esse tipo de diálogo quando, referindo-se à jurisprudência interamericana em casos nos quais o Chile tenha sido parte, ressalta que o padrão interpretativo é um elemento significativo, enquanto que nos casos em que o Chile não tenha sido parte, o juiz constitucional destaca que o padrão interpretativo é um elemento complementar de análise. Em ambas as situações, é possível observar uma diferença de intensidade, mas o relevante é que com esses critérios os juízes constitucionais chilenos se mostram dispostos a iniciar um diálogo entre juízes.

\subsubsection{Diálogo sob o modo de interpretação construtiva: diálogo construtivo}

Este diálogo se baseia no princípio de interpretação extensiva dos direitos fundamentais e o princípio de interpretação restritiva das limitações aos direitos fundamentais, estendendo protetivamente o campo de aplicação dos direitos reconhecidos $^{32}$. Então, o diálogo construtivo de juízes se produz graças a interpretações internacionais mais favoráveis que são incorporadas pelo juiz nacional no seu controle de direito interno.

Em consequência, graças ao recurso a métodos extensivos e mais favoráveis à interpretação dos direitos humanos por parte do juiz internacional ou supranacional, se produz a ampliação do campo de aplicação dos direitos reconhecidos pelo direito internacional dos direitos humanos ${ }^{33}$. Deste modo, o juiz nacional, ao incorporar o direito internacional dos direitos humanos em conjunto com as interpretações pretorianas internacionais "amplia inevitavelmente o âmbito de seu próprio controle sobre o direito interno"34.

O diálogo construtivo se produz a partir do uso de métodos de interpretação criados ou identificados pretorianamente por tribunais internacionais de direitos

\footnotetext{
${ }^{32}$ CAVALLO, Gonzalo Aguilar; ALCALÁ, Humberto Nogueira. El principio favor persona en el derecho internacional y en el derecho interno como regla de interpretación y de preferencia normativa. In: Revista de Derecho Público, Santiago, vol. 84, p. 13-43, jan./jun. 2016.

${ }^{33} \mathrm{RIOCHET}$, Diana. La conformité. L'interprétation conforme à la Convention européenne des droits de l'homme. Cahiers de l'IDEDH, Montpellier, n. 11, p. 97-128. 2007.

${ }^{34} \mathrm{RIOCHET}$, Diana. La conformité. L'interprétation conforme à la Convention européenne des droits de l'homme. Cahiers de I'IDEDH, Montpellier, n. 11, p. 97-128. 2007. p. 117.
} 
humanos, e aplicados pelos juízes nacionais, que se convertem conforme a ocasião no juiz comum de direitos humanos. Estes métodos extensivos de interpretação se fizeram presentes também no âmbito do direito internacional clássico, onde se insistiu na necessidade de considerar as novas condições da vida internacional, estimulando o juiz a determinar o Estado atual do direito, e se é necessário, fazendo-o de forma construtiva. ${ }^{35}$

Entre estes métodos, se podem mencionar, por exemplo, a interpretação evolutiva e a interpretação dinâmica. ${ }^{36} \mathrm{~A}$ interpretação evolutiva, desenvolvida pela Corte EDH e assumida pela Corte IDH, se apoia fundamentalmente na noção de que a Convenção é um instrumento vivo. ${ }^{37}$ De acordo à doutrina do instrumento vivo, o texto "se interpreta à luz das condições atuais e evolui através da interpretação da Corte" ${ }^{\prime \prime 3}$. A doutrina do instrumento vivo e, em consequência, da interpretação evolutiva, se aplica tanto ao âmbito constitucional quanto ao internacional. Nesse sentido, no terreno constitucional se alcunharam diferentes termos, tais como "constituição viva", "constituição material", "constituição invisível", "constituição paralela", os quais querem, na realidade, expressar uma necessidade na esfera dos direitos humanos, isto é, a exigência de que se requer respeito a esses textos, uma reflexão aberta e deliberativa ${ }^{39}$. Cabe ter em mente que, sobretudo no mundo atual, as constituições estão abertas a influências externas. Contudo, uma crítica à ideia de constituição viva e uma defesa do significado

${ }^{35}$ A Corte deve "determinar o estado atual do direito e inclusive, se cabível, de forma construtiva (...). Proceder de outra maneira seria ignorar a natureza do direito dos povos, que deve sempre refletir a vida internacional de onde nasce, sob pena de ser desacreditada. A forma de proceder que acaba de ser indicada é aplicada no direito público interno". INTERNATIONAL COURT OF JUSTICE. Reservations to the Conventionon Genocide, Advisory Opinion: I.C.J. Reports 1951. Disponível em: <http://www.icj-cij.org/files/case-related/12/4285.pdf>. Acesso em: 02 fev. 2018.

${ }^{36}$ Corte E.D.H.: Arrêt Tyrer, série A, no 26, p. 15, par. 31; Corte E.D.H.: Affaire Marckx c. Belgique. (Requête $\mathrm{N}^{\circ}$ 6833/74). Arrêt, para. 41; A respeito da interpretação dinâmica: "Celle qui partant du texte de la Conventionen tire une conception élargie dês droits proclames voire de l'existence de droits qui n'ont pás été primitivement perçus comme em faisant partie". ROLLAND, Patrice. Le contrôle de l'opportunité par la Cour européenne des droits de l'homme. In: ROUSSEAU, D.; SUDRE, F. (Coords.). Conseil Constitutionnel et Cour européenne des droits de I'homme - Droits et Libertés en Europe. Paris: Éditions S.T.H., 1990. p. 70; Sudre indica, referindo-se à Corte Europeia de Direitos Humanos e aos métodos de interpretação finalista e teleológica, que "a interpretação finalista é também uma interpretação evolutiva". SUDRE, Frédéric. L'interprétation dynamique de la Cour Européenne dês Droits de I'homme. Disponível em: <http://www.senat.fr/colloques/office_du_juge/ office_du_juge11.html\#fn302>. Acesso em 03 jan. 2015; WILDHABER, Luzius. La giurisprudenza evolutiva della Corte europea dei diritti umani. Pace e diritti umani, Venezia, n.1, p. 15-27. gen./apr. 2004.

${ }^{37}$ CONSELHO DA EUROPA. Tribunal Europeu dos Direitos Humanos. Pedido no 44759/98 (caso de Ferrazzini contra Itália). Par. 26. Julgado em 12/07/2001; Sobre a interpretação evolutiva do direito à vida pela Corte Interamericana de Diretos Humanos, ver CASSETTI, Luisa. II diritto di 'vivere con dignità' nella giurisprudenza della Corte Interamericana dei diritti umani. Rivista di diritto pubblico italiano, comunitario e comparato, Roma, n. 23, p. 1-17. 2010.

${ }^{38}$ WILDHABER, Luzius. La giurisprudenza evolutiva della Corte europea dei diritti umani. Pace e diritti umani, Venezia, n.1, p. 15-27. gen./apr. 2004. p. 16.

${ }^{39}$ MARTENS, Paul. L'ébauche d'une culture commune des cours suprêmes ou constitutionnelles. In: Le dialogue des juges. Actes du colloque organisé le 28 avril 2006 à I'Université libre de Bruxelles, Les Cahiers de I'Institut d'études sur la Justice. Bruxelles: Bruylant, 2007. p. 10. 
do texto que seus autores Ihe atribuíram ao momento de adotá-la foi expressa, por exemplo, por Scalia ${ }^{40}$.

Por outro lado, através da interpretação dinâmica, o juiz internacional ou supranacional não vacila em modificar suas posições anteriores acerca do sentido de um direito ${ }^{41}$. Neste sentido, realmente, os direitos humanos se mostram "vivos e vitais" através de sua interpretação ${ }^{42}$. O dinamismo interpretativo se vê refletido na ampliação dos casos de aplicação do direito e na extensão do conteúdo do direito ${ }^{43}$. 0 dinamismo interpretativo se fez presente no sistema europeu, no sistema interamericano e no âmbito constitucional chileno, levando a ação protetora do juiz, às vezes, mais além dos limites objetivos do texto ${ }^{44}$. Da perspectiva dos juízes constitucionais, por exemplo, o Tribunal Constitucional chileno não vacilou em ampliar o leque dos direitos protegidos recorrendo à Convenção Americana sobre Direitos Humanos.

Os juízes internacionais ou supranacionais recorrem à interpretação evolutiva e dinâmica com o fim de proporcionar respostas adequadas, atuais e oportunas às demandas da sociedade contemporânea. Neste trabalho, ao que parece, tentam encontrar pontos de acordo, visões compartidas ou consensos entre os Estados partes ${ }^{45}$. Isso mais parece uma quimera que uma realidade, já que a atividade do juiz é mais efetivamente baseada no desenvolvimento lógico de um conceito, de um direito ou de um princípio fundamental ${ }^{46}$. Porque o juiz, neste dinamismo interpretativo, segue mais o desenvolvimento lógico de um conceito do que a busca de consenso entre os Estados? Poderia ser porque o juiz tem o dever de dar efetividade aos direitos reconhecidos, fazer que a norma produza todos os seus efeitos, levando adiante, para isso, se

${ }^{40}$ TALBOT, Margaret. Supreme Confidence: The Jurisprudence of Justice Antonin Scalia. The New Yorker, 38 mar. 2005. Disponível em: <https://www.newyorker.com/magazine/2005/03/28/supreme-confidence>. Acesso em 04 abr. 2019.

${ }^{41}$ TULKENS, Françoise; VAN DROOGHENBROECK, Sébastien. Le droit au logement dans la Convention Européenne des Droits de I'homme. Bilan et Perspectives. In: BERNARD, Nicolas.; MERTENS, Charles. (Orgs.). Le logement dans sa multidimensionnalité. Une grande cause régionale. Belgique: Ministère de la Région Wallone, 2005.

${ }^{42}$ GIORGIANNI, Michaela.. II rapporto fra la Convenzione europea dei diritti dell'uomo e la Carta dei diritti fondamentali dell'Unione Europea nel dialogo fra le Corti europee e nazionali: il problema dell'interpretazione dei diritti umani. Diritti Comparati. 2014. Disponível em: <http://www.diritticomparati.it/2014/07/il-rapporto-fra-la-convenzione-europea-dei-diritti-delluomo-e-la-carta-dei-diritti-fondamentali-dell.html>. Acesso em 30 mar. 2019.

${ }^{43}$ SUDRE, Frédéric. A propos du dynamisme interprétatif de la Cour Européenne des droits de l'homme. La Semaine Juridique, França, n. 28, p. 335- 437. jul. 2001.

${ }^{44}$ CASSETTI, Luisa. II diritto di 'vivere con dignità' nella giurisprudenza della Corte Interamericana dei diritti umani. Rivista di diritto pubblico italiano, comunitario e comparato, Roma, n. 23, p. 1-17. 2010.

${ }^{45}$ LEVINET, Michel. La Convention européenne des droits de l'homme socle de la protection des droits de I'homme dans le droit constitutionnel européen. Revue française de droit constitutionnel, França, n. 86, p. 227-263. 2011 e PELLOUX, Robert. Les arrêts rendus par la Cour européenne des Droits de l'homme en 1980. Annuaire français de droit international, França, vol. 27, p. 286-303. 1981.

${ }^{46}$ SUDRE, Frédéric. A propos du dynamisme interprétatif de la Cour Européenne des droits de l'homme. La Semaine Juridique, França, n. 28, p. 335- 437. jul. 2001. 
for necessário, um diálogo construtivo ${ }^{47}$. A via do diálogo construtivo aumenta suas possibilidades de ocorrência na medida em que a Corte se consolida como uma fonte autorizada de direitos e padrões. ${ }^{48}$

\subsubsection{Diálogo sob o modo de interpretação antecipatória: diálogo antecipatório}

A antecipação implica numa forma de diálogo entre um juiz nacional e um juiz internacional onde o juiz nacional deve se pronunciar antes do controle de convencionalidade efetuado pelo juiz internacional, seja relacionado a temas sobre os quais o tribunal internacional tenha se pronunciado anteriormente ou não.

O diálogo antecipatório é uma manifestação do princípio de subsidiariedade que opera no âmbito dos direitos humanos ${ }^{49}$. Este princípio de subsidiariedade articula a interação entre a proteção nacional e a proteção internacional dos direitos humanos. No âmbito americano cabe ressaltar a particularidade de que "a proteção internacional é de natureza coadjuvante ou complementária em relação àquela que oferece o direito interno dos Estados". Por essa razão, o juiz nacional, sabendo disso, tem a possibilidade de se antecipar à interpretação dada pelo juiz internacional, propondoIhe neste sentido uma pauta interpretativa nova, ou melhor, mais protetora. Neste caso, poderíamos dizer, utilizando as palavras de Tizzano, que o importante aqui não é quem tem a última palavra, mas sim quem tem a primeira palavra ${ }^{50}$. Com isso, se realizaria o princípio de que os sistemas de proteção dos direitos humanos seriam complementares e, ao invés de colidirem, se enriqueceriam mutuamente.

A parte mais enriquecedora deste diálogo se poderia encontrar nos casos em que o juiz nacional deve se pronunciar sobre situações de violações dos direitos humanos em que o tribunal internacional não tenha se pronunciado com anterioridade. Nestes casos, o juiz nacional pode liderar o desenvolvimento do direito efetuando uma

\footnotetext{
${ }^{47} \mathrm{BACH}$, Natacha ; LUCAS-ALBERNI, Katia. L'utilisation du droit international au service de la politique jurisprudentielle de la Cour européenne des droits de l'homme. Cahiers de I'IDEDH, Montpellier, n. 11, p. 317-360. 2007.

48 "Enquanto a Corte Europeia se consolidou seu papel como fonte primária e oficial de direitos, doutrina e padrões, o interesse que os juízes nacionais têm em engajar construtivamente a Corte num diálogo aumenta". SWEET, Alec Stone. From the Point of View of National Judiciaries: The Role of National Courts in the Implementation of the Court's Judgments. In: EUROPEAN COURT OF HUMAN RIGHTS. Dialogue between judges. Strasbourg. 2014. p. 25. Disponível em: <http://www.echr.coe.int/Documents/Dialogue_2014_ENG.pdf>. Acesso em 05 jan. 2015.

${ }^{49}$ RANDALL, Maya Hertig. Le dialogue entre le juge suisse et le juge européen. In: BELLANGER, Francois; WERRA, Jacques (Coords.). Genève au confluent du droit interne et du droit international: Mélanges offerts par la Faculté de droit de I'Université de Genève à la Société suisse des juristes à l'occasion du congrès 2012. Zürich: Schulthess, 2012. p. 19-59.

${ }^{50}$ TIZZANO, Antonio. Les Cours européennes et l'adhésion de l'Union à la CEDH. Rivista II Diritto dell'Unione Europea, Torino, vol. 47, n. 1, p. 29-57. 2011.
} 
interpretação inovadora ${ }^{51}$. Ou ainda, se se tratam de casos onde o juiz internacional já tenha se pronunciado, o juiz nacional poderia efetuar uma interpretação extensiva, ampliando o conteúdo protetor dos direitos ${ }^{52}$. Estes casos têm a particularidade de que o juiz nacional antecede ao juiz internacional na interpretação dos direitos, podendo liderar a interpretação dos direitos reconhecidos na Convenção, se alcança que os juízes internacionais de direitos humanos dialoguem positivamente com sua argumentação ${ }^{53}$.

O diálogo antecipatório do juiz nacional em relação ao juiz internacional é duplamente útil desde a perspectiva do particular. Por uma parte, evita que o particular recorra ao amparo internacional de direitos e, por outra, melhora a efetividade dos direitos, gerando, ao mesmo tempo, um enriquecimento mútuo entre ambas as jurisdições ${ }^{54}$.

\subsubsection{Diálogo sob o modo de interpretação neutralizante: diálogo neutralizante}

A interpretação neutralizante implica uma limitação direta por parte do juiz interno de convencionalidade das obrigações que emanam da Convenção. Por meio desta interpretação se neutralizam as noções que derivam do direito internacional convencional, desenvolvidas pela jurisprudência autorizada, e se neutraliza o controle de proporcionalidade que o juiz internacional dos direitos humanos possa efetuar. Com isso, se estaria redefinindo, descendentemente, a extensão do poder do controle do juiz internacional. As principais armas desta estratégia neutralizante do juiz nacional seriam duas: por um lado, a reivindicação da denominada margem de apreciação nacional ${ }^{55}$; por outro lado, em certas ocasiões, manifestando uma ideia inversa da subsidiariedade, também se pretende hastear, para estes efeitos, a bandeira da identidade constitucional nacional ${ }^{56}$.

\footnotetext{
${ }^{51}$ GOUTTES, Régis de. La Convention européenne des droits de l'homme et le juge français. Revue internationale de droit comparé, França, vol. 51, n. 1, p. 7-20, jan./mar. 1999. Regis De Goutte salienta ainda que o juiz nacional pode encontrar na Convenção Europeia de Direitos Humanos, assim como nos princípios de interpretação por ela desenvolvidos, uma fonte de ampliação de seu poder criador do direito.

${ }^{52}$ MADELAINE, Colombine. L'anticipation. Manifestation d'un dialogue «vrai» entre juge national et juge européen? Cahiers de I'IDEDH, Montpellier, n. 11, p. 129-156. 2007.

${ }^{53}$ MILANO, Laure. Les lois rétroactives, illustration de l'effectivité du dialogue des juges, Revue Française de Droit Administratif, Lyon, n. 3, p. 447-462, maio/jun. 2006.

${ }^{54}$ MADELAINE, Colombine. L'anticipation. Manifestation d'un dialogue «vrai» entre juge national et juge européen? Cahiers de I'IDEDH, Montpellier, n. 11, p. 129-156. 2007 e MILANO, Laure. Les lois rétroactives, illustration de l'effectivité du dialogue des juges, Revue Française de Droit Administratif, Lyon, n. 3, p. 447-462, maio/jun. 2006.

${ }^{55}$ ROCA, Javier García. El margen de apreciación nacional en la interpretación del Convenio Europeo de Derechos Humanos: soberanía e integración. Madrid: Civitas-Thomson Reuters, 2009.

${ }^{56}$ LE POURHIET, Anne-Marie. L'allégeance des juges nationaux au juge européen, Constitutions: Revue de droit constitutionnel appliqué, França, n. 3, p. 363-365. 2010 e DUBOIS, Julien. La neutralisation. Dialogue des juges et interprétation neutralisante. Cahiers de I'IDEDH, Montpellier, n. 11, p. 72-96. 2007.
} 
O diálogo através da interpretação neutralizante é definido por Sudre como "uma estratégia de desvio ou prevenção direcionado a neutralizar a interpretação Europeia criando assim, por meio de uma interpretação um pouco forçada do direito nacional, incluso mediante uma espécie de reescrita da lei, uma relação de adequação entre o direito interno e a norma Europeia" ${ }^{\prime 57}$. No diálogo conforme existe concordância nas interpretações, enquanto no diálogo neutralizante há submissão na aparência, mas contradições mais ao fundo, o que, por consequência, não permite uma aplicação sistemática e plena das disposições da Convenção e não garante o respeito efetivo às suas normas ${ }^{58}$.

Em definitivo, a interpretação neutralizante anestesia os efeitos principais das normas e da interpretação autorizada dos direitos humanos. A neutralização se produz porque com a interpretação do juiz nacional é possível se apartar da interpretação internacional, sob a aparência de que se entra em diálogo com o juiz internacional, e sem aparecer vulnerando nem a norma, nem a interpretação internacional ${ }^{59}$. Trata-se de uma interpretação efetuada pelo juiz nacional, sem ter a intenção de cumprir com o padrão mínimo proveniente do corpus iuris internacional dos direitos humanos ${ }^{60}$.

Neste caso, o juiz nacional interpreta a norma convencional sob a aparência de subscrever a jurisprudência internacional, mas ao final modifica seu conteúdo ou encontra um acomodo para concluir a conformidade do direito nacional com o direito internacional dos direitos humanos ${ }^{61}$. Portanto, uma das principais consequências deste diálogo neutralizante é que o juiz nacional fará uma interpretação do direito que não estará conforme à jurisprudência internacional de direitos humanos nem com o nível de proteção que ela garante ${ }^{62}$.

Desde a perspectiva constitucional chilena, será possível pensar em dois casos que serviriam para exemplificar uma interpretação neutralizante. Um é o caso da pílula do dia seguinte, de 2008, e o outro é o caso do requerimento de inconstitucionalidade

\footnotetext{
${ }^{57}$ SUDRE, Frédéric. Les dynamiques du droit européen en début du siècle. In: À propos du dialogue des juges et du contrôle de conventionalité: Etudes en l'honneur de Jean-Claude Gautron. Paris: Pedone, 2004 ; SAGÜES, Néstor Pedro. El 'control de convencionalidad' en el sistema interamericano, y sus anticipos en el ámbito de los derechos económicos-sociales. Concordancias y diferencias con el sistema europeo. In: BOGDANDY, Armin von; FIX-FIERRO, Héctor; ANTONIAZZI, Mariela Morales; MAC-GREGOR, Eduardo Ferrer (Coords.). Construcción y papel de los derechos sociales fundamentales: Hacia un ius constitutionale commune en América Latina. México: UNAM-Instituto de Investigaciones Jurídicas de México, 2011. p. 381-417.

${ }^{58}$ DUBOIS, Julien. La neutralisation. Dialogue des juges et interprétation neutralisante. Cahiers de I'IDEDH, Montpellier, n. 11, p. 72-96. 2007.

${ }^{59}$ DUBOIS, Julien. La neutralisation. Dialogue des juges et interprétation neutralisante. Cahiers de I'IDEDH, Montpellier, n. 11, p. 72-96. 2007.

${ }^{60}$ ALCALÁ, Humberto Nogueira. Diálogo interjurisdiccional, control de convencionalidad y jurisprudencia del Tribunal Constitucional en período 2006-2011. Estudios Constitucionales, Talca, vol. 10, n. 2, p. 57-140, 2012. ${ }^{61}$ DUBOIS, Julien. La neutralisation. Dialogue des juges et interprétation neutralisante. Cahiers de I'IDEDH, Montpellier, n. 11, p. 72-96. 2007.

${ }^{62}$ DUBOIS, Julien. La neutralisation. Dialogue des juges et interprétation neutralisante. Cahiers de I'IDEDH, Montpellier, n. 11, p. 72-96. 2007.
} 
do Projeto de Lei que moderniza o sistema de relações trabalhistas de 2016. No primeiro, os juízes constitucionais recorreram não somente ao corpus iuris interamericano de direitos humanos, mas também à interpretação da própria Corte IDH para fundamentar sua resolução no sentido de que existia vida passível de proteção constitucional desde o momento da concepção - caso $n^{\circ}$ 740-2007, julgado pelo Tribunal Constitucional chileno. Recordemos que, ante a pluralidade de relatórios científicos, o Tribunal Constitucional chileno resolveu neste caso que frente a uma dúvida razoável deve prevalecer como critério hermenêutico aquele da norma mais favorável à pessoa humana. Tudo isso em circunstâncias nas quais a Corte IDH sustentou que existe uma pessoa, e, portanto, vida suscetível de ser protegida, desde o momento da implantação (Caso Artavia Murillo e outros ("Fecundação in vitro") vs. Costa Rica). Contudo, se deve reconhecer que esta declaração se fez posteriormente à sentença chilena de 2008. No segundo caso, os juízes constitucionais se apoiaram no corpus iuris internacional dos direitos trabalhistas para tentar fundamentar sua decisão de que o direito de sindicalização era um direito individual de exercício individual e, portanto, que unicamente o indivíduo é titular de tal direito, não a organização sindical - caso no 3016-2016, julgado pelo Tribunal Constitucional chileno.

\subsubsection{Diálogo sob o modo de interpretação contraditório: diálogo oposição}

O diálogo contraditório ou oposição implica uma contradição com o juiz internacional - interamericano em nosso caso -, fonte de conflitos, contudo criadora de diálogos. No diálogo oposição, há uma clara diferença de interpretações. No diálogo neutralizante existe aparente submissão ao juiz internacional, mas definitivamente sob essa aparente submissão o juiz nacional interpreta a norma para preservar o direito nacional contrário ao direito internacional - interamericano - dos direitos humanos ${ }^{63}$.

De acordo com Nogueira, a interpretação que ele denomina francamente discordante consiste em que:

a jurisdição interna do Estado considera que a resolução da CIDH constitui uma interpretação que considera incorreta, já que não avaliou corretamente a norma de direito interno, ou deixa de ponderar adequadamente outro direito ou um atributo determinado de outro direito que deve ser considerado. O tribunal nacional, em um novo caso sobre a mesma matéria, expressa seu desacordo com a CIDH fundamentadamente, explicando os motivos do desacordo no respectivo julgado, concretizando um diálogo ascendente com a CIDH'4.

${ }^{63}$ DUBOIS, Julien. La neutralisation. Dialogue des juges et interprétation neutralisante. Cahiers de I'IDEDH, Montpellier, n. 11, p. 72-96. 2007.

${ }^{64}$ ALCALÁ, Humberto Nogueira. Diálogo interjurisdiccional, control de convencionalidad y jurisprudencia del Tribunal Constitucional en período 2006-2011. Estudios Constitucionales, Talca, vol. 10, n. 2, p. 57-140, 2012. p. 97. 
Existem certas considerações que tendem a dissuadir da oposição aberta. Iniciando um diálogo com a Corte IDH, o juiz nacional sabe que tem mais possibilidades de injetar seus valores nacionais na tomada de decisões da Corte de San José que se segue a via alternativa, mais custosa, da deserção e conflito aberto. ${ }^{65}$

A seguir examinaremos se os casos Eichin e Antilef e, por certo, também Jorquera, sobre a jurisdição militar no Chile, podem ser considerados uma manifestação do papel preponderante que adquire o juiz em relação aos direitos fundamentais, e, sobretudo, uma expressão da instauração de um diálogo fecundo multinível entre juízes e direitos humanos, em alguma das vias interpretativas que acabamos de mencionar brevemente.

\section{A JURISPRUDÊNCIA CONSTITUCIONAL SOBRE JURISDIÇÃO MI- LITAR}

Nos casos Eichin e Antilef, ante o Tribunal Constitucional chileno, os juízes constitucionais utilizam o direito internacional dos direitos humanos e a jurisprudência interamericana como apoio e sustento para adotar o voto da maioria. Ambos os casos implicam em um revirement de jurisprudence em relação às decisões anteriores do Tribunal Constitucional nesta matéria. O caso Eichin se trata de um requerimento de inaplicabilidade que incide em um processo penal por lesões graves, no qual policiais haviam efetuado um disparo durante uma manifestação pacífica pela educação, e tal disparo impactou e implicou a perda do olho direito de Enrique Eichin Zambrano. ${ }^{66}$ Neste caso, com sentença datada de 6 de maio de 2014, o Tribunal Constitucional indica como inconstitucional, no cas d'espèce, a competência militar. Essa é uma jurisprudência constitucional sobre jurisdição militar quando a vítima é um civil. A sentença de maioria do caso Eichin reitera a doutrina e critérios expostos pelos ministros Hernán Vodanovic, Francisco Fernández, Carlos Carmona, Gonzalo García e Juan José Romero no caso de Francisca Jorquera Correa, caso n 2363-2012, sentença em 14 de janeiro de 2014.

Cabe apontar que o caso Jorquera, anterior ao caso Eichin, versa sobre um processo penal comum que se iniciou em consequência ao tratamento fisicamente vexatório e degradante que havia recebido a estudante Francisca Jorquera Correa por parte dos Carabineiros do Chile - policiais chilenos -, após ser detida durante o

\footnotetext{
${ }^{65}$ Ver, mutadis mutandis. SWEET, Alec Stone. From the Point of View of National Judiciaries: The Role of National Courts in the Implementation of the Court's Judgments. In: EUROPEAN COURT OF HUMAN RIGHTS. Dialogue between judges. Strasbourg. 2014. p. 25. Disponível em: <http://www.echr.coe.int/Documents/Dialogue_2014_ENG.pdf>. Acesso em 05 jan. 2015.

${ }^{66} \mathrm{~A}$ disposição legal a respeito da qual se efetua um controle de constitucionalidade é o $\operatorname{artigo} 5, \mathrm{n}^{\circ} 1$ e $\mathrm{n}^{\circ} 3$ do Código de Justiça Militar, por ser contrário ao artigo $1^{\circ}, 4^{\circ}$ e $5^{\circ}$, inciso $2^{\circ}$ e 19 , números 1 , 2 e 3 da Constituição Política. CHILE. Tribunal Constitucional. Requerimento de Inaplicabilidad por Inconstitucionalidad $n^{\circ}$ 2493-2013. Rel. Min. Hernán Vodanovic Schnake. Julgado em 06/05/2014. Disponível em: <http://www.tribunalconstitucional.cl/sentencias/busqueda-basica>. Acesso em 02 fev. 2018.
} 
desenvolvimento de uma jornada de mobilização no dia 23 de agosto de 2012. A gestão pendente em cujo contexto se deduz a ação de inaplicabilidade é de um recurso de apelação por uma declinatória de competência na qual um tribunal de garantia se declarou incompetente a favor da justiça militar pelo delito de limitações ilegítimas e tormentos.

Por sua vez, o caso Antilef trata de Marcos Antilef, carabineiro que foi vitima de tratamentos vexatórios, lesões e limitações ilegítimas - que se qualificam como tortura - por outros carabineiros nas dependências de uma prisão de carabineiros de Palmilla. O juiz de garantia se declarou incompetente e enviou o caso para a justiça militar. $\mathrm{O}$ requerimento de inaplicabilidade solicita que se declare a inconstitucionalidade do artigo $5^{\circ}, n^{\circ} 3$ do Código de Justiça Militar, que outorga à Justiça Militar competência sobre delitos comuns, por violação aos artigos $5^{\circ}$, inciso $2^{\circ} ; 19, n^{\circ} 3$, inciso $6^{\circ}$; e 83 da Constituição. Essa é uma jurisprudência constitucional que se refere a um carabineiro como vítima.

Cabe destacar que,no cas d'espèce, as elaborações constitucionais chilenas relativas aos instrumentos e às interpretações provenientes de órgãos jurisdicionais internacionais posicionam o juiz constitucional como um juiz comum de direitos humanos, interagindo com a fonte internacional, ao mesmo tempo em que realiza um controle de convencionalidade, como se descreveu na primeira parte deste trabalho.

\subsection{Os direitos reconhecidos em instrumentos internacionais de di- reitos humanos}

Nesta parte se pretende abordar a pergunta de qual é o papel e função dos direitos humanos reconhecidos em instrumentos internacionais segundo a jurisprudência do Tribunal Constitucional chileno. Em primeiro lugar, se analisarão os tratados internacionais de direitos humanos como norma fundamental do bloco constitucional de direitos. Em segundo lugar, examinaremos os direitos contidos nestes instrumentos como elementos interpretativos determinantes, e, em terceiro lugar, abordaremos o papel significativo que desempenham os padrões derivados de instrumentos internacionais de direitos humanos.

\subsubsection{Norma fundamental do bloco constitucional de direitos fundamentais}

Os juízes constitucionais afirmam que o conteúdo dos direitos reconhecidos nos instrumentos internacionais se pode aplicar diretamente como norma fundamental do bloco constitucional de direitos fundamentais ${ }^{67}$. Deste modo, mesmo quando

${ }^{67}$ ROJAS, Cláudio Nash. Derecho internacional de los derechos humanos en Chile: recepción y aplicación en el ámbito interno. Santiago de Chile: Centro de Derechos Humanos, 2012; ALCALÁ, Humberto Nogueira. Lineamientos de interpretación constitucional y del bloque constitucional de derechos. Santiago: Librotecnia, 
a Constituição chilena não reconheça em seu texto um determinado direito, isto não pode constituir um obstáculo para que o juiz constitucional lhe proporcione adequada proteção. Isso se realizaria por meio do artigo $5^{\circ}$, inciso $2^{\circ}$ da Constituição, que abre a mesma aos tratados internacionais ratificados e vigentes no Chile. No caso Eichin, os juízes constitucionais chilenos especificam que no requerimento se encontra abrangido o respeito ao mandato constitucional contido no artigo $5^{\circ}$, inciso $2^{\circ}$ da Constituição Política (Caso n².493-13, Consid. 6a).

Tal como se pode apreciar nestas considerações do Tribunal, os juízes constitucionais admitem expressamente que os tratados internacionais de direitos humanos, por mandato do artigo $5^{\circ}$, inciso $2^{\circ}$ da Constituição podem completar o catálogo constitucional de direitos ${ }^{68}$. A afirmação de princípio que realiza o Tribunal Constitucional constitui uma reiteração de sua jurisprudência constante em relação à proteção que o juiz constitucional pode efetuar com relação a direitos que se encontram amparados em tratados internacionais de direitos humanos. Por exemplo, numa sentença de 13 de maio de 2008, os juízes constitucionais reconheceram na ordem constitucional chilena e proporcionaram amparo ao direito à identidade pessoal, que não se encontra expressamente consagrado no texto constitucional ${ }^{69}$.

Além disso, o artigo $5^{\circ}$, inciso $2^{\circ}$ da Constituição Política se transforma na porta de entrada de todo o corpus iuris interamericano e internacional dos direitos humanos ao ordenamento jurídico nacional. $\mathrm{O}$ artigo $5^{\circ}$ da Constituição é, portanto, o requisito formal para que o procedimento de inaplicabilidade prospere ao encontrar um conflito entre uma norma legal e uma norma de um tratado internacional. Se isso ocorre, se produz a violação do artigo $5^{\circ}$, inciso $2^{\circ}$ da Constituição. ${ }^{70}$

2006; ALCALÁ, Humberto Nogueira. La evolución político-constitucional de Chile 1976-2005. Estudios Constitucionales, Talca, vol. 6, n. 2, p. 325-370, 2008; GONZÁLEZ, Miguel Ángel Fernández.. La aplicación por los tribunales chilenos del derecho internacional de los derechos humanos. Estudios Constitucionales, Talca, vol. 8, n. 1, p. 425-442. 2010; ARAVENA, Hugo Tortora. Bases constitucionales de la libertad de conciencia y culto en Chile. Revista de Derechos Fundamentales, Viña del Mar, n. 7, p. 87-115, 2012 e SILVA, Carolina Machado Cyrillo da. La posición jerárquica del derecho internacional de los derechos humanos en las Constituciones sudamericanas. Revista Contextos, Buenos Aires, n. 5, p. 124-135. 2013. Em um sentido crítico, ver LIZANA, Eduardo Aldunate. Derechos fundamentales. Santiago: Legal Publishing, 2008.

${ }^{68}$ Como no Caso no 1340-2009, Considerandos 9० e 10, julgado pelo Tribunal Constitucional chileno.

69 "Sobre o particular, devemos ter presente que mesmo quando a Constituição chilena não o reconheça expressamente em seu texto [o direito à identidade pessoal], isto não pode constituir um obstáculo para que o juiz constitucional lhe ofereça adequada proteção. $O$ anterior, precisamente por sua estreita vinculação com a dignidade humana e porque tampouco se pode desconhecer que se encontra sim protegido expressamente em diversos tratados internacionais ratificados pelo Chile e vigentes em nosso país, como a Convenção sobre os Direitos das Crianças (artigo 70), o Pacto Internacional de Direitos Civis e Políticos (artigo 24.2) e a Convenção Americana de Direitos Humanos (artigo 18)". CHILE. Tribunal Constitucional. Requerimento de Inaplicabilidad por Inconstitucionalidad n 834-07. Rel. Min. Marisol Peña Torres. Julgado em 13/05/2008. Considerando $23^{\circ}$. Disponível em: <http://www.tribunalconstitucional.cl/expediente>. Acesso em 02 fev. 2018.

${ }^{70}$ No caso Antilef, o Tribunal assinalou: "A vulneração dos direitos a ser ouvida por um juiz ou tribunal competente, num processo público e que seja julgado por um tribunal independente e imparcial, constitui um conjunto de infrações ao artigo $8^{\circ}$ da Convenção Americana de Direitos Humanos. Esse artigo tem sua 


\subsubsection{Elemento interpretativo determinante ou papel significativo dos padrões interna- cionais}

O conteúdo dos direitos reconhecidos nos tratados internacionais de direitos humanos pode ser assumido como elemento interpretativo determinante para extrair todos os possíveis significados dos direitos segundo os contextos nos quais aparece. Os juízes constitucionais afirmam, no caso Eichin, que os direitos reconhecidos nos tratados internacionais de direitos humanos podem ser aplicados diretamente, como parte do bloco constitucional de direitos, ou indiretamente, como elemento interpretativo determinante para a plenitude dos direitos que reconhece a Constituição Política. Assim, o Tribunal Constitucional assinala:

que então, a significação de tais direitos nos referidos instrumentos não pode ser inobservado no presente julgamento, seja porque se estime sua aplicação direta como norma fundamental do bloco constitucional de direitos, seja porque se entenda seu conteúdo como uma referência ou elemento interpretativo determinante na plena acepção dos direitos incluídos e reconhecidos pela Constituição Política ${ }^{71}$.

Além disso, em Eichin, o Tribunal Constitucional efetua uma leitura conjunta, complementária e que completa a Convenção Americana sobre Direitos Humanos e a Constituição Política do Chile, particularmente entre o artigo 8 da Convenção Americana sobre Direitos Humanos (adiante CADH) e o artigo 19, no 3 da Constituição. Desde essa perspectiva, se pode sustentar que o Tribunal Constitucional adota, positivamente, um enfoque de direitos seguindo o princípio da proteção integral. ${ }^{72} \mathrm{O}$ princípio da proteção integral possui múltiplas funções, porém uma delas consiste nesta interpretação integrada e potencializada dos direitos fundamentais. ${ }^{73}$ Contudo, deve-se precisar que

\footnotetext{
correspondência na ordem constitucional chilena através do artigo 5, inciso segundo da Constituição". CHILE, Tribunal Constitucional. Requerimento de Inaplicabilidad por Inconstitucionalidad n²492-13. Rel. Min. Gonzalo García Pino. Julgado em 17/06/2014. Considerando 23․ Disponível em: <http://www.tribunalconstitucional.cl/expediente>. Acesso em 02 fev. 2018.

${ }^{71}$ CHILE. Tribunal Constitucional. Requerimento de Inaplicabilidad por Inconstitucionalidad n²493-2013. Rel. Min. Hernán Vodanovic Schnake. Julgado em 06/05/2014. Disponível em: <http://www.tribunalconstitucional.cl/sentencias/busqueda-basica>. Acesso em 02 fev. 2018.

${ }^{72}$ Meléndez comenta que "se no processo de interpretação judicial das normas de direitos humanos se levam em consideração o que sobre cada matéria regula tanto o direito interno como o direito internacional, e se aplica - com uma visão coerentemente racional - a disposição mais favorável ao indivíduo, não somente estaria fazendo uma interpretação integral do sistema jurídico vigente, mas sim se estaria atuando como um juiz justo e racional, como um juiz da Constituição, que respeita os direitos humanos e as liberdades fundamentais". MELÉNDEZ, Florentín. Instrumentos internacionales sobre derechos humanos aplicables a la administración de justicia. Estudio constitucional comparado. Bogotá: Editorial de la Universidad del Rosario-KAS. 2012. p. 132. ${ }^{73}$ Sobre este tipo de interpretação na jurisprudência constitucional comparada, ver (STC peruano, $\mathrm{n}^{\circ} 2730$ 2006-PA/TC, par. 15; n 01412-2007-PA/TC, par. 18). "Estes valores [a liberdade, a justiça a igualdade e o pluralismo político] trazem consigo uma axiologia nuclear na interpretação de todo o direito fundamental, a
} 
a estrutura mínima para esta leitura conjunta é considerar os artigos 8 e 25 da CADH e 19, no 3 da Constituição. Deste modo, os juízes constitucionais reafirmaram a dupla articulação entre direito internacional dos direitos humanos e direito constitucional. ${ }^{74}$

Da mesma forma, os padrões que derivam dos tratados internacionais de direitos humanos desempenham um papel significativo na análise de constitucionalidade em casos de violação de direitos fundamentais, de acordo à posição tomada em Antilef. ${ }^{75}$ Efetivamente, o Tribunal Constitucional destaca, no caso Antilef, que os padrões contidos nos instrumentos internacionais terão "um papel significativo" em sua jurisprudência. ${ }^{76}$

Neste sentido, quais seriam os novos padrões em matéria de justiça militar? Os novos padrões em matéria de justiça militar a partir da ordem internacional dos direitos humanos se poderiam especificar, por exemplo, no Pacto Internacional de Direitos Civis e Políticos. ${ }^{77}$

Até agora vimos o valor atribuído aos instrumentos internacionais de direitos humanos, e passamos a examinar o valor que representa a jurisprudência internacional na reflexão dos juízes constitucionais.

combinação axiológica respectiva dá como resultado um tipo de estado, que no nosso caso se resolve numa fórmula integrativa". GÓMEZ, Maria Isabel Garrido. Aspectos e implicaciones de una interpretación integral-material de los derechos fundamentales. Derechos y Libertades: Revista del Instituto Bartolomé de las Casas, Madrid, n. 10, p. 23-52. 2001. p.27.

${ }^{74}$ “À luz de tais antecedentes, não resta dúvida de que a aplicação conjunta dos preceitos impugnados provoca uma vulneração dos direitos a ser ouvido por um juiz competente, à publicidade do processo e a ser julgado por um tribunal independente e imparcial, com transgressão dos preceitos contidos no artigo 8 da Convenção Americana sobre Direitos Humanos e no artigo 19, n 3 da Constituição Política da República". CHILE. Tribunal Constitucional. Requerimento de Inaplicabilidad por Inconstitucionalidad n²493-2013. Rel. Min. Hernán Vodanovic Schnake. Julgado em 06/05/2014. Disponível em: <http://www.tribunalconstitucional.cl/sentencias/ busqueda-basica>. Acesso em 02 fev. 2018.

${ }^{75}$ Os padrões internacionais de direitos humanos se podem compreender como "o conjunto de instrumentos internacionais de direitos humanos, negociados ou aceitos, sejam vinculantes ou não. Em consequência, os padrões incluem documentos vinculantes que codificam ou criam obrigações ou deveres jurídicos, o que se conhece comumente como hard law, assim como os documentos não vinculantes que formulam recomendações sobre normas de conduta e políticas públicas que deveriam adotar os Estados, conhecidos como soft law". INTERNATIONAL COUNCIL ON HUMAN RIGHTS. Human Rights Standards: Learning from Experience International Council on Human Rights Policy. Switzerland: Versoix. 2006. p. 4.

${ }^{76}$ "No exame para acolher este requerimento, terá um papel significativo o estabelecimento de novos padrões em matéria de justiça militar a partir da obrigação imposta ao Estado do Chile, incluindo a esta jurisdição constitucional, em cumprimento ao dever de respeitar e promover os direitos garantidos por esta Constituição e pelos tratados internacionais ratificados e vigentes no Chile". CHILE, Tribunal Constitucional. Requerimento de Inaplicabilidad por Inconstitucionalidad n 2492-13. Rel. Min. Gonzalo García Pino. Julgado em 17/06/2014. Considerando 170. Disponível em: <http://www.tribunalconstitucional.cl/expediente>. Acesso em 02 fev. 2018.

77 "Que partiremos da análise do artigo 14 do Pacto Internacional de Direitos Civis e Políticos, que estabelece um conjunto de garantias substantivas e procedimentais do devido processo, especialmente, o penal". CHILE, Tribunal Constitucional. Requerimento de Inaplicabilidad por Inconstitucionalidad n 2492-13. Rel. Min. Gonzalo García Pino. Julgado em 17/06/2014. Considerando 18. Disponível em: <http://www.tribunalconstitucional.cl/expediente>. Acesso em 02 fev. 2018 


\subsection{A jurisprudência da corte interamericana de direitos humanos}

O Tribunal Constitucional, no caso Eichin, assume expressamente uma parte muito relevante do conteúdo operativo do controle de convencionalidade, consistente em admitir que a Corte IDH é a intérprete autêntica da CADH. ${ }^{78}$ Com efeito, neste caso os juízes constitucionais reconhecem expressamente os conteúdos básicos da doutrina do controle de convencionalidade e, em íntima vinculação, conformam as obrigações internacionais do Estado. Um destes deveres consiste na obrigação de adequar o ordenamento jurídico interno aos padrões internacionais, cujas fontes principais são os princípios gerais de direito, o direito consuetudinário e o direito convencional internacional (Caso n 2493-2013, Consid. 12º). Neste caso em particular, o Tribunal Constitucional estaria referindo-se às disposições da sentença Palamara Iribarne vs. Chile, da Corte Interamericana.

Os critérios fixados pela jurisprudência da Corte IDH podem ser considerados, segundo a jurisprudência do Tribunal Constitucional, como elementos significativos para o raciocínio jurisprudencial e como elementos complementários de análise na prática judicial constitucional. A distinção entre um e outro varia, caso o Estado tenha sido parte ou não no caso interamericano de cuja jurisprudência se trata.

Desta maneira, por um lado, segundo o Tribunal Constitucional chileno, os padrões internacionais de proteção aos direitos humanos desenvolvidos pela jurisprudência derivada de casos nos quais o Estado do Chile é parte se consideram como elementos significativos para o raciocínio jurisdicional. De fato, no caso Eichin - que remete ao caso Jorquera -, os juízes constitucionais se referiram à normativa interamericana de direitos humanos e à jurisprudência da Corte IDH, particularmente àquela que emana de processos seguidos contra Chile, como o assunto Palamara Iribarne vs. Chile. Neste caso, os ministros mencionados destacam os padrões emanados desta sentença como "significativos" para resolver o requerimento. ${ }^{79}$ Este relevante critério reitera-se no caso Antilef.

Enquanto que, por outro lado, de acordo com os juízes constitucionais chilenos, os padrões internacionais de proteção aos direitos humanos desenvolvidos pela

\footnotetext{
78 "Que a Corte Interamericana de Direitos Humanos, intérprete autêntica da aludida convenção, assentou jurisprudência no sentido de que a justiça militar carece de jurisdição sobre intervenientes civis e que somente pode investigar e sancionar a afetação de bens jurídicos relacionados com a função castrense". CHILE, Tribunal Constitucional. Requerimento de Inaplicabilidad por Inconstitucionalidad no 2492-13. Rel. Min. Gonzalo García Pino. Julgado em 17/06/2014. Considerando 8. Disponível em: <http://www.tribunalconstitucional.cl/ expediente>. Acesso em 02 fev. 2018.

79 "Que mais significativo para este assunto é a jurisprudência da Corte Interamericana de Direitos Humanos, a partir da sentença da Corte IDH: Palamara Iribarne vs. Chile, Série C, no 135 a partir desta decisão CIDH/N 135/2005. Não é possível fazer uma revisão de uma extensa sentença; contudo, condensaremos alguns padrões a partir do reconhecimento de que Chile violou determinados direitos da Convenção Interamericana de Direitos Humanos". CHILE, Tribunal Constitucional. Requerimento de Inaplicabilidad por Inconstitucionalidad n 2492-13. Rel. Min. Gonzalo García Pino. Julgado em 17/06/2014. Considerando 16. Disponível em: <http://www.tribunalconstitucional.cl/expediente>. Acesso em 02 fev. 2018
} 
jurisprudência e derivados de casos nos quais o Estado do Chile não tenha sido parte se consideram como um elemento complementar de análise. Assim, no caso Eichin - que remete ao caso Jorquera -, os ministros do voto para acolhimento se referem a tais padrões como "um elemento complementar de análise".80

Seja como elemento significativo para o raciocínio jurisprudencial constitucional, seja como elemento complementar de análise, o uso que fazem os juízes constitucionais chilenos dos ensinamentos interamericanos refletem, primeiro, um diálogo entre juízes, e, segundo, este diálogo adquire, em nossa opinião, a modalidade de uma interpretação conforme e construtiva, no sentido de que melhora o padrão nacional vigente.

Cabe ressaltar que não se trata da primeira vez que o Tribunal Constitucional recorre ao uso da jurisprudência interamericana. Na maioria das sentenças se utilizou a Opinião Consultiva Colegialidade Obrigatória de jornalistas de 1985 - Opinião Consultiva da Corte IDH OC-5/85, Série A, n 5, par. 55; Caso n 2358-12 do Tribunal Constitucional chileno. Em votos separados se utilizou, por exemplo, o caso Herrera Ulloa vs. Costa Rica; Ricardo Canese vs. Paraguai e Tristán Donoso vs. Panamá, casos onde o Estado do Chile não foi parte - caso n 1798-10 do Tribunal Constitucional chileno.

\section{CONCLUSÃO}

Os casos Eichin e Antilef do Tribunal Constitucional Chileno - e também Jorquera - servem para ilustrar a evolução pela qual passou a aplicação do direito internacional dos direitos humanos pela magistratura constitucional nos últimos tempos, e a partir destes exemplos, pode-se analisar se eles são representativos de uma mudança de paradigma jurídico no direito, do surgimento de um novo direito público e do desenvolvimento prático de um diálogo entre juízes. Uma investigação maior da jurisprudência constitucional chilena fora da jurisdição militar é necessária para poder seguir construindo esse argumento.

Poderiam estes casos ser considerados uma amostra do papel protagonista do juiz sob o prisma de um novo paradigma jurídico? Quando o Tribunal Constitucional nos casos Eichin e Antilef - aplica os instrumentos internacionais de direitos humanos, e sobretudo a jurisprudência interamericana, demonstra esta mudança de paradigma, a qual se materializa pela via de um diálogo conforme.

\footnotetext{
80 "Que, por último, em matéria de padrões, cabe agregar como um elemento complementar de análise o critério que teve a própria Corte Interamericana de Direitos Humanos no caso Radilla Pacheco vs. México, em sentença de 23 de novembro de 2009, excetuando da jurisdição militar os atos delituosos cometidos por militares a respeito de bens jurídicos não militares. Sendo suas vítimas civis, sob nenhuma circunstância os julgaria a justiça militar". CHILE, Tribunal Constitucional. Requerimento de Inaplicabilidad por Inconstitucionalidad $n^{\circ}$ 2492-13. Rel. Min. Gonzalo García Pino. Julgado em 17/06/2014. Disponível em: <http://www.tribunalconstitucional.cl/expediente>. Acesso em 02 fev. 2018. Considerando 16. Disponível em: <http://www.tribunalconstitucional.cl/expediente>. Acesso em: 02 fev. 2018.
} 
Poderiam estes casos constituir um exemplo do papel protagonista do juiz no contexto de um novo direito público? Eichin e Antilef constituem, em nosso modo de ver, exemplos pragmáticos deste novo direito público cuja criação já não releva a autoridade exclusiva do Estado. Neste sentido, o juiz nacional desempenha um papel de destaque. Por isso, o papel protagonista do juiz é que um dos traços distintivos dessa mudança de paradigma e novo direito público. Eichin e Antilef o deixaram sumamente claro. Os juízes constitucionais instauram um diálogo entre juízes multinível, que aponta a adequar o Código de Justiça Militar e a prática judicial existente a respeito da competência dos tribunais militares, aos padrões mais favoráveis desenvolvidos pretorianamente pelo juiz interamericano. Para estes efeitos, o Tribunal Constitucional recorre aos instrumentos internacionais convencionais, mas, sobretudo, utiliza de forma crescente métodos interpretativos modernos e idôneos no campo dos direitos humanos, demonstrativos de um diálogo crescente de caráter multinível.

Existe nestes casos um diálogo entre juízes? Ainda, Eichin e Antilef demonstram uma tímida mas promissora preocupação dos juízes constitucionais por estabelecer um diálogo com os juízes interamericanos. Do anterior, demonstra não somente a referência à jurisprudência relativa ao Chile, tal como no caso Palamara Iribarne, e também o uso da jurisprudência referente a outros Estados partes na Convenção Americana sobre Direitos Humanos, tal como o caso Radilla Pacheco vs. México. Em Eichin e Antilef, os juízes constitucionais adequaram o Código de Justiça Militar e, além disso, a interpretação que até o momento provinha da prática judicial, aos padrões estabelecidos pela Convenção Americana sobre Direitos Humanos e à interpretação da Corte IDH. Por essa razão, como se sustentou ao largo desse estudo, se poderia sustentar que o Tribunal Constitucional chileno, em Eichin e Antilef, instaurou um diálogo com os juízes interamericanos sob a modalidade da interpretação conforme. Antes do desenvolvimento deste artigo, e posteriormente a essas sentenças, a Corte Suprema se uniu sistematicamente ao critério fixado pelo Tribunal Constitucional, estabelecendo de forma horizontal um frutífero diálogo conforme. Por fim, veremos se no futuro o Tribunal Constitucional persistirá nesta vontade de estabelecer um diálogo multinível entre juízes que aponte não à submissão mas sim à prevalência da solução mais favorável ao indivíduo.

\section{REFERÊNCIAS}

ALCALÁ, Humberto Nogueira. Derechos fundamentales, bloque constitucional de derechos, diálogo interjurisdiccional y control de convencionalidad. México: Ubijus, 2014.

ALCALÁ, Humberto Nogueira. Diálogo interjurisdiccional, control de convencionalidad y jurisprudencia del Tribunal Constitucional en período 2006-2011. Estudios Constitucionales, Talca, vol. 10, n. 2, p. 57-140, 2012. 
ALCALÁ, Humberto Nogueira. La evolución político-constitucional de Chile 1976-2005. Estudios Constitucionales, Talca, vol. 6, n. 2, p. 325-370, 2008.

ALCALÁ, Humberto Nogueira. Lineamientos de interpretación constitucional y del bloque constitucional de derechos. Santiago: Librotecnia, 2006.

ANDRIANTSIMBAZOVINA, Joël. La prise en compte de la Convention européenne des droits de I'homme par le Conseil constitutionnel, continuité ou évolution?, Cahiers du Conseil Constitutionnel, [s.I.], vol. 18, p. 148-153, 2005.

ARAVENA, Hugo Tortora. Bases constitucionales de la libertad de conciencia y culto en Chile. Revista de Derechos Fundamentales, Viña del Mar, n. 7, p. 87-115, 2012.

BOGDANDY, Armin Von. Ius constitutionale commune latinoamericanum. Una aclaración conceptual desde una perspectiva europea. In: PÉREZ, L. R. G.; VALADÉS, D. (Coords.). El constitucionalismo contemporáneo. Homenaje a Jorge Carpizo. México: Instituto de Investigaciones jurídicas, UNAM, 2013. p. 39-66.

CASSETTI, Luisa. II diritto di 'vivere con dignità' nella giurisprudenza della Corte Interamericana dei diritti umani. Rivista di diritto pubblico italiano, comunitario e comparato, Roma, n. 23, p. 1-17. 2010.

CAVALLO, Gonzalo Aguilar. Diálogo judicial multinivel. In: ALCALÁ, Humberto Nogueira (Coord.). Diálogo judicial multinivel y principios interpretativos favor persona y de proporcionalidad. Santiago: Librotecnia, 2013. p. 55-102.

CAVALLO, Gonzalo Aguilar; ALCALÁ, Humberto Nogueira. El principio favor persona en el derecho internacional y en el derecho interno como regla de interpretación y de preferencia normativa. In: Revista de Derecho Público, Santiago, vol. 84, p. 13-43, jan./jun. 2016.

CHILE. Tribunal Constitucional. Requerimento de Inaplicabilidad por Inconstitucionalidad $n^{\circ}$ 2493-2013. Rel. Min. Hernán Vodanovic Schnake. Julgado em 06/05/2014. Disponível em: <http://www.tribunalconstitucional.cl/sentencias/busqueda-basica>. Acesso em 02 fev. 2018.

CHILE. Tribunal Constitucional. Requerimento de Inaplicabilidad por Inconstitucionalidad n॰ 83407. Rel. Min. Marisol Peña Torres. Julgado em 13/05/2008. Disponível em: <http://www.tribunalconstitucional.cl/expediente>. Acesso em 02 fev. 2018.

CHILE, Tribunal Constitucional. Requerimento de Inaplicabilidad por Inconstitucionalidad $n^{\circ}$ 2492-13. Rel. Min. Gonzalo García Pino. Julgado em 17/06/2014. Disponível em: <http://www. tribunalconstitucional.cl/expediente>. Acesso em 02 fev. 2018.

CHILE. Corte Suprema de Chile. Caso Conselhos de Guerra n² 27.543-16. 2016. Disponível em: <http://www.pjud.cl/corte-suprema>. Acesso em: 29 jan. 2018.

CHILE. Tribunal Constitucional. Requerimento de Inaplicabilidade por Inconstitucionalidade I-212016, RUC 16-2-0173337-9. Rel. Min. Pilar Arellano Gómez. Julgado em 04/07/2016. Disponível em: <http://www.tribunalconstitucional.cl/expediente?rol=3119>. Acesso em 30 fev. 2015. 
CONSELHO DA EUROPA. Tribunal Europeu dos Direitos Humanos. Pedido no 44759/98 (caso de Ferrazzini contra Itália). Par. 26. Julgado em 12/07/2001.

CONSELHO DA EUROPA. Tribunal Europeu dos Direitos Humanos. Pedido no 6538/74 (caso do Sunday Times contra o Reino Unido). Par. 61. Julgamento em 26/04/1979.

CORTE INTERAMERICANA DE DERECHOS HUMANOS. Caso "Niños de la Calle" - Villagrán Morales y otros vs. Guatemala. Julgado em 19/09/1999.

CORTE INTERAMERICANA DE DERECHOS HUMANOS. Opinião Consultiva OC-17/02. Condição Jurídica e Direitos Humanos da Criança. Publicada em 28/08/2002.

DUBOIS, Julien. La neutralisation. Dialogue des juges et interprétation neutralisante. Cahiers de I'IDEDH, Montpellier, n. 11, p. 72-96. 2007.

DULITZKY, Ariel. E.. An Inter-American Constitutional Court? The Invention of the Conventionality Control by the Inter-American Court of Human Rights. Texas International Law Journal, Texas, vol. 50, n. 1, p. 45-93, dec./feb. 2015.

GIORGIANNI, Michaela.. II rapporto fra la Convenzione europea dei diritti dell'uomo e la Carta dei diritti fondamentali dell'Unione Europea nel dialogo fra le Corti europee e nazionali: il problema dell'interpretazione dei diritti umani. Diritti Comparati. 2014. Disponível em: <http://www.diritticomparati.it/2014/07/il-rapporto-fra-la-convenzione-europea-dei-diritti-delluomo-e-la-carta-dei-diritti-fondamentali-dell.html>.

GÓMEZ, Maria Isabel Garrido. Aspectos e implicaciones de una interpretación integral-material de los derechos fundamentales. Derechos y Libertades: Revista del Instituto Bartolomé de las Casas, Madrid, n. 10, p. 23-52. 2001.

GONZÁLEZ, Miguel Ángel Fernández. La aplicación por los tribunales chilenos del derecho internacional de los derechos humanos. Estudios Constitucionales, Talca, vol. 8, n. 1, p. 425-442. 2010.

GOUTTES, Régis de. La Convention européenne des droits de l'homme et le juge français. Revue internationale de droit comparé, França, vol. 51, n. 1, p. 7-20, jan./mar. 1999.

GRABARCZYK, Kataryna. Dialogue des juges: éléments d'analyse. Cahiers de I'IDEDH, Montpellier, n. 11, p. 10-41, 2007.

INTERNATIONAL COUNCIL ON HUMAN RIGHTS. Human Rights Standards: Learning from Experience International Council on Human Rights Policy. Switzerland: Versoix. 2006.

INTERNATIONAL COURT OF JUSTICE. Reservations to the Convention on Genocide, Advisory Opinion: I.C.J. Reports 1951. Disponível em: <http://www.icj-cij.org/files/case-related/12/4285. pdf $>$. Acesso em: 02 fev. 2018.

LAVADE, Anne. Constitution et Europe ou le juge constitutionnel au cœur des rapports de systèmes, Cahiers du Conseil Constitutionnel, França, n. 18, p. 133-137. 2005. 
LE POURHIET, Anne-Marie. L'allégeance des juges nationaux au juge européen, Constitutions: Revue de droit constitutionnel appliqué, França, n. 3, p. 363-365. 2010.

LEVINET, Michel. La Convention européenne des droits de l'homme socle de la protection des droits de l'homme dans le droit constitutionnel européen. Revue française de droit constitutionnel, França, n. 86, p. 227-263. 2011.

LIZANA, Eduardo Aldunate. Derechos fundamentales. Santiago: Legal Publishing, 2008.

MAC-GREGOR, Eduardo Ferrer. Interpretación conforme y control difuso de convencionalidad. El nuevo paradigma para el juez mexicano. Estudios Constitucionales, Talca, vol. 9, n 2, p. 531-622. 2011.

MADELAINE, Colombine. L'anticipation. Manifestation d'un dialogue «vrai» entre juge national et juge européen? Cahiers de I'IDEDH, Montpellier, n. 11, p. 129-156. 2007.

MARTENS, Paul. L'ébauche d'une culture commune des cours suprêmes ou constitutionnelles. In: Le dialogue des juges. Actes du colloque organisé le 28 avril 2006 à I'Université libre de Bruxelles, Les Cahiers de I'Institut d'études sur la Justice. Bruxelles: Bruylant, 2007.

MAUS, Didier. La Charte des Droits Fondamentaux de I'Union Européenne et la Protection des Droits de l'Homme en Europe. 2004. Disponível em: http://www.us-rs.si/media/zbornik.pdf. Acesso em: 31 fev. 2018. p. 14-26.

MELÉNDEZ, Florentín. Instrumentos internacionales sobre derechos humanos aplicables a la administración de justicia. Estudio constitucional comparado. Bogotá: Editorial de la Universidad del Rosario-KAS. 2012.

MILANO, Laure. Les lois rétroactives, illustration de l'effectivité du dialogue des juges, Revue Française de Droit Administratif, Lyon, n. 3, p. 447-462, maio/jun. 2006.

MOTOLESE, Luisa. La Corte Europea dei Diritti dell'Uomo: Tecniche di decisione e criteri di interpretazione conforme alla Convenzione Europea. 2013. Disponível em: <http://www.contabilita-pubblica.it/2013/Dottrina/Motolese.pdf >. Acesso em 5 jan. 2015.

PELLOUX, Robert. Les arrêts rendus par la Cour européenne des Droits de I'homme en 1980. Annuaire français de droit international, França, vol. 27, p. 286-303. 1981.

RANDALL, Maya Hertig. Le dialogue entre le juge suisse et le juge européen. In: BELLANGER, Francois; WERRA, Jacques (Coords.). Genève au confluent du droit interne et du droit international: Mélanges offerts par la Faculté de droit de l'Université de Genève à la Société suisse des juristes à l'occasion du congrès 2012. Zürich: Schulthess, 2012. p. 19-59.

RIOCHET, Diana. La conformité. L'interprétation conforme à la Convention européenne des droits de I'homme. Cahiers de I'IDEDH, Montpellier, n. 11, p. 97-128. 2007.

ROCA, Javier García. El margen de apreciación nacional en la interpretación del Convenio Europeo de Derechos Humanos: soberanía e integración. Madrid: Civitas-Thomson Reuters, 2009. 
ROJAS, Cláudio Nash. Derecho internacional de los derechos humanos en Chile: recepción y aplicación en el ámbito interno. Santiago de Chile: Centro de Derechos Humanos, 2012.

ROLLAND, Patrice. Le contrôle de l'opportunité par la Cour européenne des droits de l'homme. In: ROUSSEAU, D.; SUDRE, F. (Coords.). Conseil Constitutionnel et Cour européenne des droits de I'homme - Droits et Libertés en Europe. Paris: Éditions S.T.H., 1990. p. 70-74.

SAGÜES, Néstor Pedro. El 'control de convencionalidad' en el sistema interamericano, y sus anticipos en el ámbito de los derechos económicos-sociales. Concordancias y diferencias con el sistema europeo. In: BOGDANDY, Armin von; FIX-FIERRO, Héctor; ANTONIAZZI, Mariela Morales; MAC-GREGOR, Eduardo Ferrer (Coords.). Construcción y papel de los derechos sociales fundamentales: Hacia un ius constitutionale commune en América Latina. México: UNAM-Instituto de Investigaciones Jurídicas de México, 2011. p. 381-417.

SILVA, Carolina Machado Cyrillo da. La posición jerárquica del derecho internacional de los derechos humanos en las Constituciones sudamericanas. Revista Contextos, Buenos Aires, n. 5, p. 124-135. 2013.

SUDRE, Frédéric. Les dynamiques du droit européen en début du siècle. In: À propos du dialogue des juges et du contrôle de conventionalité: Etudes en I'honneur de Jean-Claude Gautron. Paris: Pedone, 2004.

SUDRE, Frédéric. A propos du dynamisme interprétatif de la Cour Européenne des droits de I'homme. La Semaine Juridique, França, n. 28, p. 335- 437. jul. 2001.

SUDRE, Frédéric. Avant-propos. Cahiers de I'IDEDH, Montpellier, n. 11, p. 7-9. 2007.

SUDRE, Frédéric. Droit européen et international des droits de l'homme. Paris: PUF, 2003.

SUDRE, Frédéric. L'interprétation dynamique de la Cour Européenne dês Droits de l'homme. Disponível em: <http://www.senat.fr/colloques/office_du_juge/office_du_juge11.html\#fn302>. Acesso em 03 jan. 2015.

SUXE, Hervé. La dimension objective du dialogue des juges. Cahiers de I'IDEDH, Montpellier, n. 11, p. 158-191. 2007.

SWEET, Alec Stone. From the Point of View of National Judiciaries: The Role of National Courts in the Implementation of the Court's Judgments. In: EUROPEAN COURT OF HUMAN RIGHTS. Dialogue between judges. Strasbourg. 2014. p. 25. Disponível em: <http://www.echr.coe.int/Documents/Dialogue_2014_ENG.pdf>. Acesso em 05 jan. 2015.

TALBOT, Margaret. Supreme Confidence: The Jurisprudence of Justice Antonin Scalia. The New Yorker, 38 mar. 2005. Disponível em: <https://www.newyorker.com/magazine/2005/03/28/supreme-confidence>. Acesso em 04 abr. 2019.

TIZZANO, Antonio. Les Cours européennes et l'adhésion de I'Union à la CEDH. Rivista II Diritto dell'Unione Europea, Torino, vol. 47, n. 1, p. 29-57. 2011. 
TRIA, Lucia. La tutela dei diritti fondamentali. In: Le tecniche di interrelazione normativa indicate dalla Corte costituzionale. L'abilità di usare il patrimonio di sapienza giuridica ereditato dal passato per preparare il futuro. 2014. p. 34. Disponível em: <http://www.cortecostituzionale.it/ documenti/convegni_seminari/STU_274.pdf>. Acesso em 31 fev. 2018.

ALEMANHA. Tribunal Constitucional Alemão, BVerfGE 37, 27, Caso Handelsgesellschaft, ("Solange I"). Julgado em 29/05/1974. Disponível em: <https://www.bundesverfassungsgericht.de>.

ALEMANHA. Tribunal Constitucional Alemão, BVerfGE 73, 339, 2 BvR 197/83, Caso “Solange II". Julgado em 22/10/1986. Disponível em: <https://www.bundesverfassungsgericht.de>.

TULKENS, Françoise; VAN DROOGHENBROECK, Sébastien. Le droit au logement dans la Convention Européenne des Droits de l'homme. Bilan et Perspectives. In: BERNARD, Nicolas.; MERTENS, Charles. (Orgs.). Le logement dans sa multidimensionnalité. Une grande cause régionale. Belgique: Ministère de la Région Wallone, 2005.

BACH, Natacha ; LUCAS-ALBERNI, Katia. L'utilisation du droit international au service de la politique jurisprudentielle de la Cour européenne des droits de l'homme. Cahiers de I'IDEDH, Montpellier, n. 11, p. 317-360. 2007.

WILDHABER, Luzius. La giurisprudenza evolutiva della Corte europea dei diritti umani. Pace e diritti umani, Venezia, n.1, p. 15-27. gen./apr. 2004. 